\title{
Somatostatin receptor-based imaging and therapy of gastroenteropancreatic neuroendocrine tumors
}

\author{
Dik J Kwekkeboom ${ }^{1}$, Boen L Kam ${ }^{1}$, Martijn van Essen ${ }^{1}$, Jaap J M Teunissen ${ }^{1}$, \\ Casper H J van Eijck ${ }^{2}$, Roelf Valkema ${ }^{1}$, Marion de Jong ${ }^{1}$, Wouter W de Herder ${ }^{3}$ \\ and Eric P Krenning ${ }^{1}$
}

Departments of ${ }^{1}$ Nuclear Medicine, ${ }^{2}$ Surgery and ${ }^{3}$ Internal Medicine, Erasmus Medical Center, s-Gravendijkwal 230, 3015 CE Rotterdam, The Netherlands

(Correspondence should be addressed to D J Kwekkeboom; Email: d.j.kwekkeboom @erasmusmc.nl)

\begin{abstract}
Somatostatin receptor imaging (SRI) with $\left[{ }^{111}\right.$ In-DTPA ${ }^{0}$ octreotide has proven its role in the diagnosis and staging of gastroenteropancreatic neuroendocrine tumors (GEPNETs). Newer radiolabeled somatostatin analogs which can be used in positron emission tomography (PET) imaging, and which have a higher affinity for the somatostatin receptor, especially receptor subtype-2, have been developed. It would be desirable, however, if one radiolabeled analog became the new standard for PET imaging, because the current application of a multitude of analogs implies a fragmented knowledge on the interpretation of the images that are obtained in clinical practice. In our view, the most likely candidates for such a universal PET tracer for SRI are $\left[{ }^{68} \mathrm{Ga}\right.$-DOTA $\left.{ }^{0}, \mathrm{Tyr}^{3}\right]$ octreotate or $\left[{ }^{68} \mathrm{Ga}\right.$-DOTA $\left.{ }^{0}, \mathrm{Tyr}^{3}\right]$ octreotide. Treatment with radiolabeled somatostatin analogs is a promising new tool in the management of patients with inoperable or metastasized neuroendocrine tumors. Symptomatic improvement may occur with all ${ }^{111} \mathrm{In}-,{ }^{90} \mathrm{Y}-$, or ${ }^{177} \mathrm{Lu}$-labeled somatostatin analogs that have been used for peptide receptor radionuclide therapy (PRRT). The results that were obtained with $\left[{ }^{90} \mathrm{Y}-\mathrm{DOTA}{ }^{0}, \mathrm{Tyr}^{3}\right]$ octreotide and $\left[{ }^{177}\right.$ Lu-DOTA $\left.^{0}, \mathrm{Tyr}^{3}\right]$ octreotate are very encouraging in terms of tumor regression. Also, if kidney protective agents are used, the side effects of this therapy are few and mild, and the median duration of the therapy response for these radiopharmaceuticals is 30 and 40 months respectively. The patients' self-assessed quality of life increases significantly after treatment with $\left[{ }^{177}\right.$ Lu-DOTA $^{0}$, Tyr $\left.^{3}\right]$ octreotate. Lastly, compared to historical controls, there is a benefit in overall survival of several years from the time of diagnosis in patients treated with [ $\left.{ }^{177} \mathrm{Lu}^{-D O T A^{0}}, \mathrm{Tyr}^{3}\right]$ octreotate. These data compare favorably with the limited number of alternative treatment approaches. If more widespread use of PRRT can be guaranteed, such therapy may well become the therapy of first choice in patients with metastasized or inoperable GEPNETs.
\end{abstract}

Endocrine-Related Cancer (2010) 17 R53-R73

\section{Introduction}

Peptide receptor scintigraphy in man started with the in vivo demonstration of somatostatin receptor-positive tumors in patients using a radioiodinated somatostatin analog (Krenning et al. 1989). Later, other radiolabeled somatostatin analogs were developed, and two of these subsequently became commercially available. Also, over the past decade, positron emission tomography (PET) tracers for somatostatin receptor imaging (SRI) were developed, and the superiority of the image quality as well as the increased sensitivity in tumor site detection using these newer tracers and PET cameras has been reported by various research groups.

Starting in the 1990s, attempts at treatment with radiolabeled somatostatin analogs were undertaken in patients with inoperable and/or metastasized neuroendocrine tumors. Improvements in particularly the peptides used (with higher receptor affinity) and the radionuclides that were applied (with $\beta$ instead of $\gamma$ emission), together with precautions to limit the 
radiation dose to the kidneys and the bone marrow, led to better results with a virtually negligible percentage of serious adverse events.

The first part of this review will deal with somatostatin receptor-based imaging, the second part with somatostatin receptor-based radionuclide therapy. In both sections, we attempt to summarize the results obtained with each method available to date, compared to other methods in current use and, where relevant, historical controls. The final section of this review gives a summing up and suggestions for the future.

\section{Somatostatin receptor-based radionuclide imaging}

Because the radioiodinated somatostatin analog that was first used for imaging in patients, $\left[{ }^{123}{\left.\mathrm{I}, \mathrm{Tyr}^{3}\right]-}^{3}\right.$ octreotide, had several drawbacks, soon a chelated and ${ }^{111}$ In-labeled somatostatin analog, $\left[{ }^{111}\right.$ In-DTPA $\left.{ }^{0}\right]$ octreotide, was developed. $\left[{ }^{111}\right.$ In-DTPA $\left.{ }^{0}\right]$ octreotide (OctreoScan, Covidien, Petten, The Netherlands) is commercially available and is the most commonly used agent for SRI. The recommended scanning protocol for $\left[{ }^{111}\right.$ In-DTPA $\left.{ }^{0}\right]$ octreotide scintigraphy as well as the scanning results is summarized below.

The preferred dose of $\left[{ }^{111}\right.$ In-DTPA $\left.{ }^{0}\right]$ octreotide (with at least $10 \mu \mathrm{g}$ of the peptide) is about $200 \mathrm{MBq}$. With such a dose, it is possible to perform single-photon emission computed tomography (SPECT), which may increase the sensitivity to detect somatostatin receptor-positive tissues and gives a better anatomical delineation than planar views. The acquisition of sufficient counts per view and also obtaining spot images with a sufficient counting time instead of performing whole-body scanning with a too low count density are other important points that may make the difference between a successful localizing study and a disappointing one. For a scanning protocol, view the procedure guideline for somatostatin receptor scintigraphy with $\left[{ }^{111}\right.$ In-DTPA ${ }^{0}$ ]octreotide, published by the Society of Nuclear Medicine (Balon et al. 2001).

\section{$\left[{ }^{111}\right.$ In-DTPA $\left.{ }^{0}\right]$ octreotide scintigraphy: normal scintigraphic findings and artifacts}

Normal scintigraphic features include visualization of the thyroid, spleen, liver, and kidneys, and in a proportion of patients the pituitary gland (Fig. 1). Also, the urinary bladder and the bowel are usually visualized to a variable degree. The visualization of the pituitary, thyroid, and spleen is due to receptor binding. Uptake in the kidneys is for the most part due to reabsorption of the radiolabeled peptide in the renal

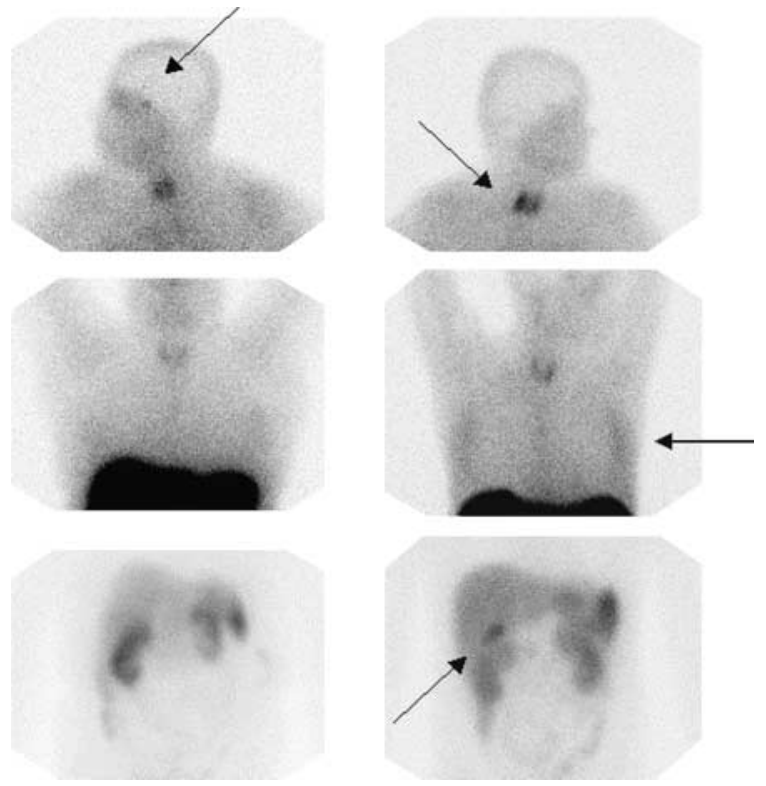

Figure 1 Normal distribution in SRI. Variable visualization of the pituitary and thyroid (arrows, upper panel). Faint breast uptake can sometimes be seen in women (right middle panel, arrow). Normal uptake in the liver, spleen, and the kidneys, and also some bowel activity in the lower panel. Gallbladder visualization in the lower right panel (arrow). Anterior views.

tubular cells after glomerular filtration. There is a predominant renal clearance of the somatostatin analog, although hepatobiliary clearance into the bowel also occurs, necessitating the use of laxatives in order to facilitate the interpretation of abdominal images.

False-positive results of SRI with $\left[{ }^{111} \mathrm{In}_{-} \mathrm{DTPA}^{0}\right]$ octreotide have been reported. In virtually all cases, the term 'false-positive' is a misnomer because somatostatin receptor-positive lesions that are not related to the pathology, for which the investigation is performed, are present. Many of these have been reviewed by Gibril et al. (1999). The most common of these are radiation pneumonitis, accessory spleen, focal collection of stools, surgical scar tissue, gallbladder uptake, nodular goiter, ventral hernia, bacterial pneumonia, respiratory infections, common cold (nasal uptake), cerebrovascular accident, concomitant granulomatous disease, diffuse breast uptake, adrenal uptake, urine contamination, and concomitant second primary tumor.

Diminished uptake in the spleen due to ongoing treatment with (unlabeled) octreotide may occur, which may be accompanied by a lower liver uptake. In case of hepatic metastases, this phenomenon may be misinterpreted as a better uptake in the liver metastases. During octreotide treatment, the uptake of $\left[{ }^{111} \mathrm{In}-\mathrm{DTPA}{ }^{0}\right]$ octreotide in somatostatin receptorpositive tumors is also diminished. This may lead to 
a lower detection rate of somatostatin receptor-positive lesions, although there are also reports of improved tumor-to-background ratio after pretreatment with nonradioactive octreotide. Other causes for a potential false-negative study are: the presence of unlabeled somatostatin, either because of octreotide therapy or resulting from production of somatostatin by the tumor itself; the presence of different somatostatin receptor subtypes that have different affinities for the radioligand, which may be important especially in patients with insulinomas and medullary thyroid carcinomas; the presence of liver metastases of neuroendocrine tumors that have a similar degree of tracer accumulation as the normal liver and so appear isointense (Tables 1 and 2).

\section{Imaging results of $\left[{ }^{111}\right.$ In-DTPA ${ }^{0}$ ]octreotide scintigraphy in neuroendocrine and other tumors}

Somatostatin receptors have been identified in vitro in a large number of human neoplasias. A high incidence and density of somatostatin receptors are found, in particular, in neuroendocrine tumors, such as pituitary adenoma, pancreatic islet cell tumor, carcinoid, pheochromocytoma, paraganglioma, medullary thyroid cancer, and small cell lung carcinoma (Reubi 1997). Tumors of the nervous system including meningioma, neuroblastoma, and medulloblastoma also express very often a high density of somatostatin receptors. But also tumors not known to be classically originating from endocrine or neural cells, such as lymphoma, breast cancer, renal cell cancer, hepatocellular cancer, prostate cancer, sarcoma, and gastric cancer, can express somatostatin receptors. In the majority of these tumors, the somatostatin receptor subtype- 2 is predominantly expressed, although low amounts of

Table 1 Pitfalls and causes of potential misinterpretation of positive results with $\left[{ }^{111} \operatorname{In}-\right.$ DTPA $^{0}$ ]octreotide scintigraphy

Radiation pneumonitis

Accessory spleen

Focal collection of stools

Surgical scar tissue

Gallbladder uptake

Nodular goiter

Ventral hernia

Bacterial pneumonia

Respiratory infections

Common cold (nasal uptake)

Cerebrovascular accident

Concomitant granulomatous disease

Diffuse breast uptake

Adrenal uptake

Urine contamination

Concomitant second primary tumor
Table 2 Causes of potential misinterpretation of negative results with $\left[{ }^{111}\right.$ In-DTPA ${ }^{0}$ ]octreotide scintigraphy

Presence of unlabeled somatostatin, either because of octreotide therapy or resulting from production of somatostatin by the tumor itself, may lower tumor detectability

Different somatostatin receptor subtypes have different affinities for the radioligand; variable tumor differentiation and receptor expression also influence tumor detectability. This may be important especially in patients with insulinomas and medullary thyroid carcinomas

Liver metastases of neuroendocrine tumors may appear isointense because of a similar degree of tracer accumulation by the normal liver. Correlation with anatomic imaging and/or SPECT imaging may be helpful

other somatostatin receptor subtypes may be concomitantly present (Reubi et al. 2001). It should also be emphasized that selected nontumoral lesions may express somatostatin receptors. For instance, active granulomas in sarcoidosis express somatostatin receptors on the epithelioid cells, and inflamed joints in active rheumatoid arthritis express somatostatin receptors, preferentially located in the proliferating synovial vessels (Reubi et al. 1994). The expression of somatostatin receptors is therefore not specific for tumoral pathologies.

Imaging results in tumors and other diseases are listed and subdivided according to the reported sensitivity of SRI with $\left[{ }^{111}\right.$ In-DTPA $\left.{ }^{0}\right]$ octreotide in Table 3.

Common indications for $\left[{ }^{111} \mathrm{In}-\mathrm{DTPA}^{0}\right]$ octreotide scintigraphy include the detection and localization of a variety of neuroendocrine and other tumors and their metastases, the staging of patients with neuroendocrine tumors, the follow-up of patients with known disease, and lastly the selection of patients with inoperable and/or metastatic tumors for peptide receptor radionuclide therapy (PRRT).

\section{Newer ligands for SRI}

${ }^{99}{ }^{\mathrm{m}}$ Tc-Depreotide (Neotect, Diatide, Londonderry, NH, USA) is another commercially available somatostatin analog that has been approved specifically for the detection of lung cancer in patients with pulmonary nodules (Menda \& Kahn 2002). Because of the relatively high abdominal background and the impossibility to perform delayed imaging due to the short halflife of the tracer, it is less suited for the detection of abdominal neuroendocrine tumors (Lebtahi et al. 2002).

$\left[{ }^{111}\right.$ In-DOTA]lanreotide is a SRI agent with a slightly different affinity profile than $\left[{ }^{111}\right.$ In-DTPA $\left.^{0}\right]$ octreotide (Reubi et al. 2000). In comparison with $\left[{ }^{111}\right.$ In-DTPA $\left.{ }^{0}\right]$ octreotide, it has a lower sensitivity to 
Table 3 Sensitivity of somatostatin receptor imaging using $\left[{ }^{111}\right.$ In-DTPA ${ }^{0}$ octreotide

High sensitivity

Pituitary tumors (Kwekkeboom et al. 1999)

GEPNETs

Gastrinomas (De Kerviler et al. 1994, Gibril et al. 1996)

Nonfunctioning endocrine pancreatic tumors (Krenning et al. 1993, Lebtahi et al. 1997)

Functioning endocrine pancreatic tumors except insulinomas (Krenning et al. 1993, Lebtahi et al. 1997)

Carcinoids (Kwekkeboom et al. 1993a, Westlin et al. 1993, Ahlman et al. 1994, Kalkner et al. 1995)

Paragangliomas (Kwekkeboom et al. 1993b, Telischi et al. 2000, Duet et al. 2003)

Small cell lung cancer (Kirsch et al. 1994, Kwekkeboom et al. 1994, Bombardieri et al. 1995, Reisinger et al. 1998)

Meningiomas (Haldemann et al. 1995, Schmidt et al. 1998)

Sarcoidosis and other granulomatous diseases (Vanhagen et al. 1994, Kwekkeboom et al. 1998)

Graves' disease and Graves' ophthalmopathy (Postema et al. 1994, Krassas et al. 1995)

\section{Intermediate sensitivity}

Insulinoma (Krenning et al. 1993, Zimmer et al. 1996)

Medullary thyroid carcinoma (Kwekkeboom et al. 1993c, Tisell et al. 1997, Adams et al. 1998)

Differentiated thyroid carcinoma (including Hurthle cell

carcinoma) (Postema et al. 1996, Gulec et al. 1998,

Haslinghuis et al. 2001)

Breast cancer (Van Eijck et al. 1994)

Lymphoma (NHL, HL) (Lugtenburg et al. 2001a,b)

Pheochromocytoma (Van der Harst et al. 2001)

Astrocytoma (Schmidt et al. 1998)

High sensitivity, detection rate $>75 \%$; intermediate sensitivity, detection rate $40-75 \%$. Sensitivity is either patient or lesion based. GEPNET, gastroenteropancreatic neuroendocrine tumor; NHL, non-Hodgkin lymphoma; HL, Hodgkin's lymphoma.

demonstrate neuroendocrine tumors, but it may have advantages in other tumors, for instance in differentiated thyroid cancer (Virgolini et al. 2002).

Also, other somatostatin analogs labeled with $\gamma$-emitting radionuclides have been proposed, and more recently analogs labeled with positron-emitting radionuclides have been tested in patients. Especially, the latter analogs that are used for imaging with PET cameras or hybrid PET-CT cameras have great potential because of two advantages that they have over $\gamma$-emitting analogs. First, many of them have a better affinity for the somatostatin receptor subtype-2, which is most commonly expressed by neuroendocrine tumors, and also there are some analogs that target other somatostatin receptor subtypes better, and are therewith potentially also useful for visualizing tumors that express these other receptor subtypes, but not the subtype-2. Secondly, the better spatial resolution of PET imaging and the combined anatomical and functional information that is obtained with the hybrid
PET-CT technique result in a higher sensitivity of this type of scanning. An overview of clinical results in patients with gastroenteropancreatic neuroendocrine tumors (GEPNETs) obtained with somatostatin analogs other than $\left[{ }^{111}\right.$ In-DTPA $\left.{ }^{0}\right]$ octreotide (OctreoScan) is given in Table 4.

Reviewing the results with these newer analogs, there are also causes for concern. First, many studies that compare these newer analogs, either compare to $\left[{ }^{111}\right.$ In-DTPA $\left.{ }^{0}\right]$ octreotide scintigraphy using inadequate scanning protocols, or they describe comparisons between two or more new analogs and therefore lack a validated reference method. Secondly, the multitude of new PET analogs that are applied leads to a situation in which each center has to build up its own knowledge on normal findings and artifacts of their scanning methods. This hampers the exchange of data and their shared interpretation. It is, however, likely that one of the new PET analogs, $\left[{ }^{68} \mathrm{Ga}\right.$-DOTA $\left.^{0}, \mathrm{Tyr}^{3}\right]$ octreotide or $\left[{ }^{68} \mathrm{Ga}\right.$-DOTA ${ }^{0}$, $\mathrm{Tyr}^{3}$ ]octreotate, becomes the new standard for SRI using PET. This is because these somatostatin analogs have a high affinity for the somatostatin receptor subtype-2, and because ${ }^{68} \mathrm{Ga}$ is a generator product instead of a cyclotron-produced product, a relatively simple labeling can be performed on an everyday basis. An additional reason why $\left[{ }^{68} \mathrm{Ga}^{-D O T A}{ }^{0}, \mathrm{Tyr}^{3}\right]$ octreotide or $\left[{ }^{68} \mathrm{Ga}\right.$-DOTA $\left.{ }^{0}, \mathrm{Tyr}^{3}\right]$ octreotate is the likely new standard analog for PET imaging is that their ${ }^{90} \mathrm{Y}$ - or ${ }^{177} \mathrm{Lu}$-labeled counterparts are used for PRRT, and that it seems desirable that the peptide that is used in diagnostic imaging mimicks as closely as possible the peptide that is used for therapy.

Other radionuclide-coupled ligands that are independent of the presence of somatostatin receptors for visualization of the tumors have also been tested in patients with GEPNETs. The oldest of these, ${ }^{123} \mathrm{I}-\mathrm{MIBG}$, performs poorer than $\left[{ }^{111} \mathrm{In}-\mathrm{DTPA}^{0}\right]-$ octreotide scintigraphy (Quigley et al. 2005).

${ }^{18}$ F-FDG PET scanning has gained importance for tumor staging and treatment response evaluation for a number of tumor types. The method is based on glucose consumption by the tumors, and therefore, fast growing tumors usually show high tracer uptake. However, ${ }^{18}$ F-FDG PET is less suited for GEPNETs, because of their slow growing nature. Therefore, it is recommended only in cases with negative SRI findings (Belhocine et al. 2002), a situation which usually correlates with more aggressive behavior and faster growth.

Newer PET radioligands that have been clinically tested in patients with GEPNETs comprise ${ }^{18} \mathrm{~F}$-DOPA and ${ }^{11}$ C-5-hydroxy-tryptophan (Koopmans et al. 2006, 2008). 
Table 4 Results of the clinical application of somatostatin receptor imaging using various ligands in patients with gastroenteropancreatic neuroendocrine tumors

\begin{tabular}{|c|c|c|c|}
\hline Radioligand & Reported results & Comments & References \\
\hline$\left[{ }^{99 m} \mathrm{Tc}-\mathrm{EDDA} / \mathrm{HYNIC}{ }^{0}\right]$ octreotate & $\begin{array}{l}\text { Better than }\left[{ }^{111} \operatorname{In}-\mathrm{DTPA}^{0}\right] \\
\text { octreotide }\end{array}$ & $\begin{array}{l}{\left[{ }^{111} \text { In-DTPA }{ }^{0}\right] \text { octreotide scan }} \\
\text { protocol inadequate }\end{array}$ & $\begin{array}{l}\text { Hubalewska-Dydejczyk et al. } \\
\text { (2006) }\end{array}$ \\
\hline $\begin{array}{l}{\left[{ }^{68} \mathrm{Ga}-\mathrm{DOTA}{ }^{0}, \mathrm{Tyr}^{3}\right] \text { octreotide }} \\
{\left[{ }^{99 \mathrm{~m}} \mathrm{Tc} \text {-HYNIC }{ }^{0}\right] \text { octreotide }} \\
{\left[{ }^{111} \mathrm{In}-\mathrm{DOTA}{ }^{0}\right] \text { octreotide }}\end{array}$ & $\begin{array}{l}{\left[{ }^{68} \mathrm{Ga}^{-D O T A}{ }^{0}, \mathrm{Tyr}^{3}\right] \text { octreotide }} \\
\text { PET better than other two } \\
\text { methods }\end{array}$ & $\begin{array}{l}\text { No comparison to } \\
{\left[{ }^{111} \operatorname{In}-\mathrm{DTPA}^{0}\right] \text { octreotide }}\end{array}$ & Gabriel et al. (2007) \\
\hline$\left[{ }^{68} \mathrm{Ga}-\mathrm{DOTA}{ }^{0}, \mathrm{Tyr}^{3}\right]$ octreotide & $\begin{array}{l}\text { Better than }\left[{ }^{111} \text { In-DTPA }{ }^{0}\right] \\
\text { octreotide SPECT }\end{array}$ & $\begin{array}{l}{\left[{ }^{111} \text { In-DTPA }{ }^{0}\right] \text { octreotide scan }} \\
\text { protocol inadequate }\end{array}$ & Buchmann et al. (2007) \\
\hline$\left[\right.$ Gluc-Lys $\left.{ }^{0},\left[{ }^{18} \mathrm{~F}\right] \mathrm{FP}\right]$ octreotate & $\begin{array}{l}\text { Better than }\left[{ }^{111} \text { In-DTPA }{ }^{0}\right] \\
\text { octreotide }\end{array}$ & & Meisetschläger et al. (2006) \\
\hline$\left[{ }^{68} \mathrm{Ga}-\mathrm{DOTA}{ }^{0}, \mathrm{Tyr}^{3}\right]$ octreotide & $\begin{array}{l}\text { Better than }\left[{ }^{111} \ln -\text { DTPA }^{0}\right] \\
\text { octreotide }\end{array}$ & $\begin{array}{l}{\left[{ }^{111} \text { In-DTPA }{ }^{0}\right] \text { octreotide scan }} \\
\text { protocol inadequate }\end{array}$ & Hofmann et al. (2001) \\
\hline $\begin{array}{l}{\left[{ }^{68} \mathrm{Ga}-\mathrm{DOTA}, 1-\text { naphthylalanin }{ }^{3}\right]} \\
\text { octreotide }\end{array}$ & $\begin{array}{l}\text { Useful information additional } \\
\text { to CT }\end{array}$ & $\begin{array}{l}\text { No comparison to } \\
{\left[{ }^{111} \operatorname{In}-\mathrm{DTPA} \mathrm{A}^{0}\right] \text { octreotide }}\end{array}$ & Fanti et al. (2008) \\
\hline 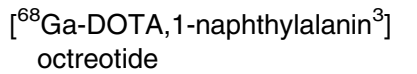 & Better than ${ }^{18} \mathrm{~F}$-DOPA & $\begin{array}{l}\text { No comparison to } \\
{\left[{ }^{111} \ln -D_{\left.T P A^{0}\right] \text { octreotide }}\right.}\end{array}$ & Ambrosini et al. (2008) \\
\hline${ }^{99 \mathrm{~m}} \mathrm{Tc}$-Depreotide & $\begin{array}{l}\text { Inferior to }\left[{ }^{111} \text { In-DTPA }{ }^{0}\right] \\
\text { octreotide }\end{array}$ & & Lebtahi et al. (2002) \\
\hline$\left[{ }^{111}\right.$ In-DOTA]lanreotide & $\begin{array}{l}\text { Inferior to }\left[{ }^{111} \ln -\mathrm{DOTA}{ }^{0}, \mathrm{Tyr}^{3}\right] \\
\text { octreotide }\end{array}$ & $\begin{array}{l}\text { No comparison to } \\
{\left[{ }^{111} \text { In-DTPA }{ }^{0} \text { octreotide }\right.}\end{array}$ & Virgolini et al. (2002) \\
\hline
\end{tabular}

PET with these ligands was reported to be more sensitive than SRI with $\left[{ }^{111}\right.$ In-DTPA $\left.{ }^{0}\right]$ octreotide. These PET ligands, however, have to be synthesized in the close vicinity of or in the hospital where the administration to the patient is to take place. Also, both ${ }^{18}$ F-DOPA and ${ }^{11}$ C-5-hydroxy-tryptophan, unlike the radiolabeled somatostatin analogs used in PET, lack a sequel in PRRT.

\section{Somatostatin receptor-based radionuclide therapy}

GEPNETs, which comprise functioning and nonfunctioning endocrine pancreatic tumors and carcinoids, are usually slow growing. When metastasized, treatment with somatostatin analogs results in reduced hormonal overproduction and symptomatic relief in most cases. Treatment with somatostatin analogs is however seldom successful in terms of tumor size reduction (Arnold et al. 1993, Janson \& Oberg 1993, Ducreux et al. 2000). However, it was recently shown that the long-acting somatostatin analog Octreotide LAR significantly lengthens time to tumor progression compared with placebo in patients with functionally active and inactive metastatic midgut NETs (Rinke et al. 2009).

A new treatment modality for patients with inoperable or metastasized endocrine GEP tumors is the use of radiolabeled somatostatin analogs. The majority of endocrine GEP tumors possess somatostatin receptors and can therefore be visualized with
SRI. A logical sequence to this tumor visualization in vivo was therefore to also try to treat these patients with radiolabeled somatostatin analogs. Virtually without exception, the patients who were treated with PRRT had well-differentiated GEPNETs (grade 1 or 2 according to the World Health Organization (WHO) classification). In the sections that follow on different forms of PRRT, reported tumor responses are based on WHO or South-Western Oncology Group criteria, unless stated differently.

\section{Studies with $\left[{ }^{111}\right.$ In-DTPA ${ }^{0}$ ]octreotide}

Because at that time no other chelated somatostatin analogs labeled with $\beta$-emitting radionuclides were available, early studies in the mid- to late 1990s used $\left[{ }^{111}\right.$ In-DTPA $\left.{ }^{0}\right]$ octreotide for PRRT. Initial studies with high dosages of $\left[{ }^{111}\right.$ In-DTPA ${ }^{0}$ ]octreotide in patients with metastasized neuroendocrine tumors were encouraging with regard to symptom relief, but partial remissions (PRs) were exceptional. Two out of 26 patients with GEPNETs who were treated with high dosages of $\left[{ }^{111} \mathrm{In}-\mathrm{DTPA}{ }^{0}\right]$ octreotide, and received a total cumulative dose of more than $550 \mathrm{mCi}(20 \mathrm{GBq})$, had a decrease in tumor size between 25 and $50 \%$ as measured on CT scans (Valkema et al. 2002). None, however, had PR (Table 5). In another study in 27 patients with GEPNETs, PR was reported in 2/26 patients with measurable disease (Anthony et al. 2002; Table 5). Both series had relatively high numbers of patients who were in a poor clinical condition upon study entry. Also, many had progressive disease when 
Table 5 Tumor responses in patients with gastroenteropancreatic neuroendocrine tumors, treated with different radiolabeled somatostatin analogs (adapted with permission from Kwekkeboom et al. (2005a) copyright 2005 Society of Nuclear Medicine, Inc.)

\begin{tabular}{|c|c|c|c|c|c|c|c|c|}
\hline & \multicolumn{8}{|c|}{ Tumor response } \\
\hline & Ligand & $\begin{array}{l}\text { Patient } \\
\text { number }\end{array}$ & CR & PR & MR & SD & PD & CR + PR (\%) \\
\hline \multicolumn{9}{|l|}{ Center (reference) } \\
\hline $\begin{array}{l}\text { Rotterdam (Valkema } \\
\text { et al. 2002) }\end{array}$ & $\begin{array}{c}{\left[{ }^{111} \text { In-DTPA }{ }^{0}\right]} \\
\text { octreotide }\end{array}$ & 26 & 0 & 0 & $5(19 \%)$ & $11(42 \%)$ & $10(38 \%)$ & 0 \\
\hline $\begin{array}{l}\text { New Orleans (Anthony } \\
\text { et al. 2002) }\end{array}$ & $\begin{array}{c}{\left[{ }^{111} \text { In-DTPA }{ }^{0}\right]} \\
\text { octreotide }\end{array}$ & 26 & 0 & $2(8 \%)$ & NA & $21(81 \%)$ & $3(12 \%)$ & 8 \\
\hline Milan (Bodei et al. 2003) & $\begin{array}{l}{\left[{ }^{90} \mathrm{Y}-\mathrm{DOTA} \mathrm{A}^{0}, \mathrm{Tyr}^{3}\right]} \\
\text { octreotide }\end{array}$ & 21 & 0 & $6(29 \%)$ & NA & $11(52 \%)$ & $4(19 \%)$ & 29 \\
\hline $\begin{array}{l}\text { Basel (Waldherr et al. } \\
2001,2002 a)\end{array}$ & $\begin{array}{l}{\left[{ }^{90} \mathrm{Y}-\mathrm{DOTA} \mathrm{A}^{0}, \mathrm{Tyr}^{3}\right]} \\
\text { octreotide }\end{array}$ & 74 & $3(4 \%)$ & $15(20 \%)$ & NA & $48(65 \%)$ & $8(11 \%)$ & 24 \\
\hline $\begin{array}{l}\text { Basel (Waldherr et al. } \\
2002 b \text { ) }\end{array}$ & $\begin{array}{l}{\left[{ }^{90} \mathrm{Y} \text {-DOTA }{ }^{0}, \mathrm{Tyr}^{3}\right]} \\
\text { octreotide }\end{array}$ & 33 & $2(6 \%)$ & $9(27 \%)$ & NA & $19(57 \%)$ & $3(9 \%)$ & 33 \\
\hline $\begin{array}{l}\text { Rotterdam (Valkema } \\
\text { et al. 2006) }\end{array}$ & $\begin{array}{l}{\left[{ }^{90} \mathrm{Y}-\mathrm{DOTA} \mathrm{C}^{0}, \mathrm{Tyr}^{3}\right]} \\
\text { octreotide }\end{array}$ & 58 & 0 & $5(9 \%)$ & $7(12 \%)$ & $33(61 \%)$ & $10(19 \%)$ & 9 \\
\hline $\begin{array}{l}\text { Rotterdam (Kwekkeboom } \\
\text { et al. 2008) }\end{array}$ & $\begin{array}{c}{\left[{ }^{177} \text { Lu-DOTA }^{0},-\right.} \\
\text { Tyr }^{3} \text { ]octreotate }\end{array}$ & 310 & $5(2 \%)$ & $86(28 \%)$ & $51(16 \%)$ & 107 (35\%) & $61(20 \%)$ & 29 \\
\hline
\end{tabular}

entering the study. The most common toxicity in both series was due to bone marrow suppression. Serious side effects consisted of leukemia and myelodysplastic syndrome (MDS) in three patients who had been treated with total cumulative doses of $>2.7 \mathrm{Ci}$ $(100 \mathrm{GBq})$ (and estimated bone marrow radiation doses of more than $3 \mathrm{~Gy}$; Valkema et al. 2002). One of these patients had also been treated with chemotherapy, which may have contributed to or caused this complication. Anthony et al. (2002) reported renal insufficiency in one patient, which was probably not treatment related, but due to preexistent retroperitoneal fibrosis. Transient liver toxicity was observed in three patients with widespread liver metastases. Although in both series favorable effects on symptomatology were reported, CT-assessed tumor regression was observed only in rare cases. This is not surprising, since ${ }^{111}$ In-coupled peptides are not ideal for PRRT because of the small particle range and therefore short tissue penetration.

\section{Studies with ${ }^{90} \mathrm{Y}$-DOTA ${ }^{0}, \mathrm{Tyr}^{3}$ ]octreotide}

The next generation of somatostatin receptor-mediated radionuclide therapy used a modified somatostatin analog, $\left[\mathrm{Tyr}^{3}\right]$ octreotide, with a higher affinity for the somatostatin receptor subtype-2, and a different chelator, DOTA instead of DTPA, in order to ensure a more stable binding of the intended $\beta$-emitting radionuclide ${ }^{90}$ Yttrium $\left({ }^{90} \mathrm{Y}\right)$. Using this compound $\left({ }^{90}\right.$ Y-DOTATOC; OctreoTher), different phase- 1 and -2 PRRT trials have been performed.
Otte et al. (1999) and Waldherr et al. (2001, 2002a; Basel, Switzerland) reported different phase-1 and -2 studies in patients with GEPNETs. In their first reports, using a dose-escalating scheme of four treatment sessions up to a cumulative dose of $160 \mathrm{mCi}$ $(6 \mathrm{GBq}) / \mathrm{m}^{2}$, and at which time renal protection with amino acid infusion was not performed in half of the patients, renal insufficiency developed in 4/29 patients. The overall response rate in patients with GEPNETs who were either treated with $160 \mathrm{mCi}(6 \mathrm{GBq}) / \mathrm{m}^{2}$ (Waldherr et al. 2001), or, in a later study, with $200 \mathrm{mCi}(7.4 \mathrm{GBq}) / \mathrm{m}^{2}$ in four doses (Waldherr et al. $2002 a$ ), was $24 \%$ (Table 5). In a subsequent study, with the same dose of $200 \mathrm{mCi}(7.4 \mathrm{GBq}) / \mathrm{m}^{2}$ administered in two sessions, complete and PRs were found in onethird of 36 patients (Waldherr et al. 2002b; Table 5). It should be emphasized, however, that this was not a randomized trial comparing two dosing schemes.

Chinol et al. (2002) (Milan, Italy) described dosimetric and dose-finding studies with $\left[{ }^{90} \mathrm{Y}^{-D_{O T A}}{ }^{0}\right.$, $\mathrm{Tyr}^{3}$ ]octreotide with and without the administration of kidney-protecting agents. No major acute reactions were observed up to an administered dose of $150 \mathrm{mCi}$ (5.6 GBq) per cycle. Reversible grade 3 hematological toxicity was found in $43 \%$ of patients injected with $140 \mathrm{mCi}(5.2 \mathrm{GBq})$, which was defined as the maximum tolerated dose per cycle. None of the patients developed acute or delayed kidney failure, although follow-up was short. Partial and complete remissions were reported by the same group in $28 \%$ of 87 patients with neuroendocrine tumors (Paganelli et al. 2002). 
In a more detailed publication from the same group, Bodei et al. (2003) reported the results of a phase-1 study in 40 patients with somatostatin receptorpositive tumors, of whom 21 had GEPNETs. Cumulative total treatment doses ranged from 160 to $300 \mathrm{mCi}(5.9-11.1 \mathrm{GBq})$, given in two treatment cycles. Six of $21(29 \%)$ patients had tumor regression (Table 5). Median duration of the response was 9 months.

Another study with $\left[{ }^{90} \mathrm{Y}-\mathrm{DOTA}{ }^{0}, \mathrm{Tyr}^{3}\right]$ octreotide is a multicenter phase-1 study which was performed in Rotterdam (The Netherlands), Brussels (Belgium), and Tampa (USA), in which 58 patients received escalating doses up to $400 \mathrm{mCi}(14.8 \mathrm{GBq}) / \mathrm{m}^{2}$ in four cycles or up to $250 \mathrm{mCi}(9.3 \mathrm{GBq}) / \mathrm{m}^{2}$ single dose, without reaching the maximum tolerated single dose (Valkema et al. 2006). The cumulative radiation dose to kidneys was limited to $27 \mathrm{~Gy}$. All received amino acids concomitant with $\left[{ }^{90} \mathrm{Y}\right.$-DOTA $\left.{ }^{0}, \mathrm{Tyr}^{3}\right]$ octreotide for kidney protection. Three patients had dose-limiting toxicity: one had liver toxicity, one had thrombocytopenia grade $4\left(<25 \times 10^{9} / 1\right)$, and one had MDS. Out of 58 patients, five (9\%) had PR and seven (12\%) had a minor response (MR; $25-50 \%$ tumor volume reduction; Table 5). The median time to progression in the 44 patients who had either stable disease (SD), MR, or PR was 30 months (Valkema et al. 2003).

Bushnell et al. (2003) (Iowa City, USA) reported a favorable clinical response as determined by a scoring system that included weight, patient-assessed health score, Karnofsky score, and tumor-related symptoms, in 14/21 patients who were treated with a total cumulative dose of $360 \mathrm{mCi}\left[{ }^{90} \mathrm{Y}\right.$-DOTA ${ }^{0}, \mathrm{Tyr}^{3}$ ] octreotide in three treatment cycles.

Despite differences in protocols used, complete plus PRs in most of the different studies with $\left[{ }^{90} \mathrm{Y}^{-D O T A}{ }^{0}\right.$,
$\mathrm{Tyr}^{3}$ ]octreotide are in the same range, in between 10 and $30 \%$, and therefore better than those obtained with $\left[{ }^{111} \mathrm{In}-\mathrm{DTPA}{ }^{0}\right]$ octreotide.

\section{Studies with $\left[{ }^{177}{ }^{\text {Lu-DOTA }}{ }^{0}\right.$, Tyr $^{3}$ ]octreotate}

The somatostatin analog $\left[\mathrm{DTPA}^{0}, \mathrm{Tyr}^{3}\right]$ octreotate differs from $\left[\mathrm{DTPA}^{0}, \mathrm{Tyr}^{3}\right.$ ] octreotide only in that the C-terminal threoninol is replaced with threonine. Compared with [DTPA ${ }^{0}, \mathrm{Tyr}^{3}$ ] octreotide, it shows an improved binding to somatostatin receptor-positive tissues in animal experiments (De Jong et al. 1998). Also, its DOTA-coupled counterpart, [DOTA ${ }^{0}, \mathrm{Tyr}^{3}$ ]octreotate, labeled with the $\beta$ - and $\gamma$-emitting radionuclide ${ }^{177}$ Lutetium $\left({ }^{177} \mathrm{Lu}\right)$ was reported to be very successful in terms of tumor regression and animal survival in a rat model (Erion et al. 1999). Reubi et al. (2000) reported a ninefold increase in affinity for the somatostatin receptor subtype 2 for $\left[\right.$ DOTA $^{0}$, Tyr $^{3}$ ] octreotate if compared with [DOTA ${ }^{0}$, $\mathrm{Tyr}^{3}$ ]octreotide, and a six- to sevenfold increase in affinity for their Yttrium-loaded counterparts (Table 6).

In a comparison in patients, it was found that the uptake of radioactivity, expressed as percentage of the injected dose of $\left[{ }^{177} \mathrm{Lu}\right.$-DOTA $\left.{ }^{0}, \mathrm{Tyr}^{3}\right]$ octreotate, was comparable to that after $\left[{ }^{111}\right.$ In-DTPA $\left.{ }^{0}\right]$ octreotide for kidneys, spleen, and liver, but was three- to fourfold higher for four of five tumors (Kwekkeboom et al. 2001). Therefore, $\left[{ }^{177} \mathrm{Lu}-\mathrm{DOTA}{ }^{0}, \mathrm{Tyr}^{3}\right]$ octreotate potentially represents an important improvement because of the higher absorbed doses that can be achieved to most tumors with about equal doses to potentially dose-limiting organs and because of the lower tissue penetration range of ${ }^{177} \mathrm{Lu}$ if compared with ${ }^{90} \mathrm{Y}$, which may be especially important for small tumors. Also, when we compared the residence time in tumors for $\left[{ }^{177} \mathrm{Lu}^{\mathrm{DOTA}}{ }^{0}, \mathrm{Tyr}^{3}\right]$ octreotide and

Table 6 Affinity profiles $\left(\mathrm{IC}_{50}\right)$ for human $\mathrm{sst}_{1}-\mathrm{sst}_{5}$ receptors of a series of somatostatin analogs

\begin{tabular}{|c|c|c|c|c|c|}
\hline Peptide & sst $_{1}$ & sst $_{2}$ & sst $_{3}$ & sst $_{4}$ & sst $_{5}$ \\
\hline Somatostatin-28 & $5.2(0.3)$ & $2.7(0.3)$ & $7.7(0.9)$ & $5.6(0.4)$ & $4.0(0.3)$ \\
\hline Octreotide & $>10000$ & $2.0(0.7)$ & $187(55)$ & $>1000$ & $22(6)$ \\
\hline DTPA-octreotide & $>10000$ & $12(2)$ & $376(84)$ & $>1000$ & $299(50)$ \\
\hline In-DTPA-octreotide & $>10000$ & $22(3.6)$ & $182(13)$ & $>1000$ & $237(52)$ \\
\hline DOTA-[Tyr $\left.{ }^{3}\right]$ octreotide & $>10000$ & $14(2.6)$ & $880(324)$ & $>1000$ & $393(84)$ \\
\hline DOTA-[Tyr ${ }^{3}$ ]octreotate & $>10000$ & $1.5(0.4)$ & $>1000$ & $453(176)$ & $547(160)$ \\
\hline DOTA-lanreotide & $>10000$ & $26(3.4)$ & 771 (229) & $>10000$ & 73 (12) \\
\hline Y-DOTA-[Tyr $\left.{ }^{3}\right]$ octreotide & $>10000$ & $11(1.7)$ & 389 (135) & $>10000$ & $114(29)$ \\
\hline Y-DOTA-[Tyr $\left.{ }^{3}\right]$ octreotate & $>10000$ & $1.6(0.4)$ & $>1000$ & $523(239)$ & $187(50)$ \\
\hline Y-DOTA-lanreotide & $>10000$ & $23(5)$ & $290(105)$ & $>10000$ & $16(3.4)$ \\
\hline
\end{tabular}

All values are half maximal inhibitory concentration ( $\left.\mathrm{IC}_{50}\right)$ (S.E.M.) in $\mathrm{nM}$ (adapted from Reubi et al. (2000) with kind permission from Springer Science+Business Media: copyright 2000 European Journal of Nuclear Medicine). No data are available for Lu-loaded somatostatin analogs. 


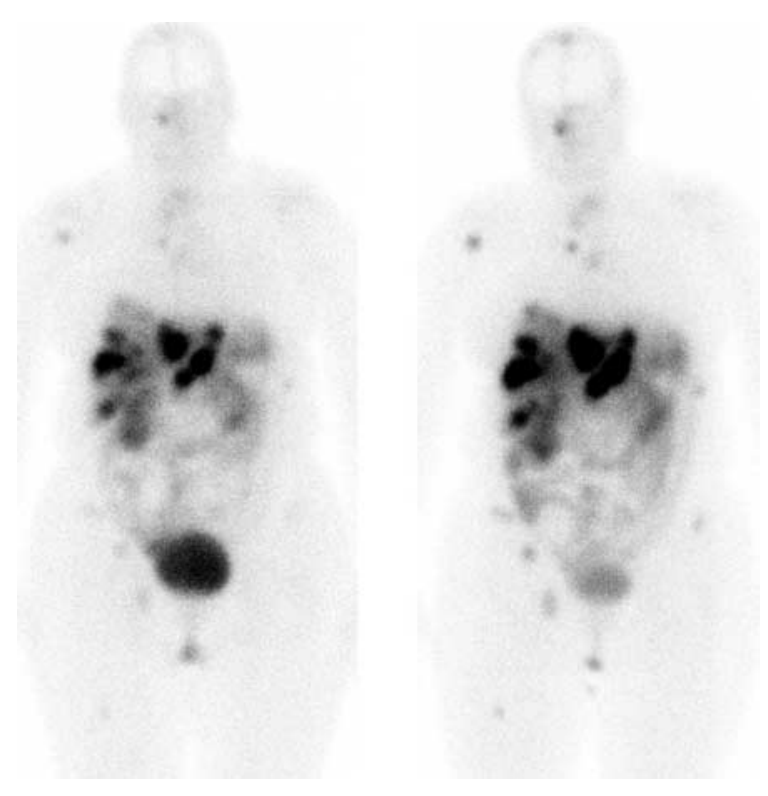

Figure 2 Planar anterior scintigrams 1 day after the administration of $3700 \mathrm{MBq}(100 \mathrm{mCi})$ of [ ${ }^{177} \mathrm{Lu}-\mathrm{DOTA}{ }^{0}, \mathrm{Tyr}^{3}$ ]octreotide (left) or $\left[{ }^{177}{ }^{\text {Lu-DOTA }}{ }^{\mathrm{O}}, \mathrm{Tyr}^{3}\right]$ octreotate (right) in the same patient with liver and bone metastases from a GEPNET. Note the higher uptake in the tumor sites after $\left[{ }^{177}\right.$ Lu-DOTA $\left.{ }^{0}, \mathrm{Tyr}^{3}\right]$ octreotate, with similar uptake in liver and spleen (adapted from Esser et al. (2006) with kind permission from Springer Science + Business Media: copyright 2006 European Journal of Nuclear Medicine and Molecular Imaging).

$\left[{ }^{177} \mathrm{Lu}-\mathrm{DOTA}{ }^{0}, \mathrm{Tyr}^{3}\right]$ octreotate in the same patients in a therapeutical setting, we found a factor 2.1 in favor of $\left[{ }^{177} \mathrm{Lu}-\mathrm{DOTA}{ }^{0}, \mathrm{Tyr}^{3}\right]$ octreotate (Esser et al. 2006; Fig. 2). We therefore think that ${ }^{177} \mathrm{Lu}$-octreotate is the radiolabeled somatostatin analog of choice when performing PRRT.

Consistent with two earlier reports (Kwekkeboom et al. 2003, 2005b), a recent analysis of the side effects and treatment outcome of $\left[{ }^{177} \mathrm{Lu}-\mathrm{DOTA}{ }^{0}, \mathrm{Tyr}^{3}\right]$ octreotate therapy was described in 504 and 310 patients with neuroendocrine GEP tumors respectively (Kwekkeboom et al. 2008).

In the 504 patients, acute side effects occurring within $24 \mathrm{~h}$ after the administration of the radiopharmaceutical were nausea after $25 \%$ of administrations, vomiting after $10 \%$ of administrations, and abdominal discomfort or pain after $10 \%$ of administrations. Six patients were hospitalized within 2 days of the administration of the radiopharmaceutical because of hormone-related crises (De Keizer et al. 2008). All patients recovered after adequate care.

Subacute, hematological toxicity, WHO toxicity grade 3 or 4 , occurred $4-8$ weeks after $3.6 \%$ of administrations, or, expressed patient-based, after at least one of several treatments in $9.5 \%$ of patients.
Factors that were associated with a higher frequency of hematological toxicity grade 3 or 4 were age over 70 years at treatment start, a history with previous chemotherapy treatment, creatinine clearance (estimated with Cockroft's formula) $\leq 60 \mathrm{ml} / \mathrm{min}$, and the presence of bone metastases. When these factors were tested together in multivariate logistic regression, low creatinine clearance was a significant factor both for grade $3 / 4$ thrombocytopenia $(P<0.001)$, as for any hematological grade $3 / 4$ toxicity $(P<0.001)$, whereas a history with previous chemotherapy was less significant in predicting thrombocytopenia $(P<0.05$; Fig. 3). Creatinine clearance $\leq 60 \mathrm{ml} / \mathrm{min}$ was significantly more frequent in patients aged 70 or more $\left(P<0.001, \chi^{2}\right.$ test; Fig. 3$)$. Temporary hairloss (WHO grade 1 ; no baldness) occurred in $62 \%$ of patients.
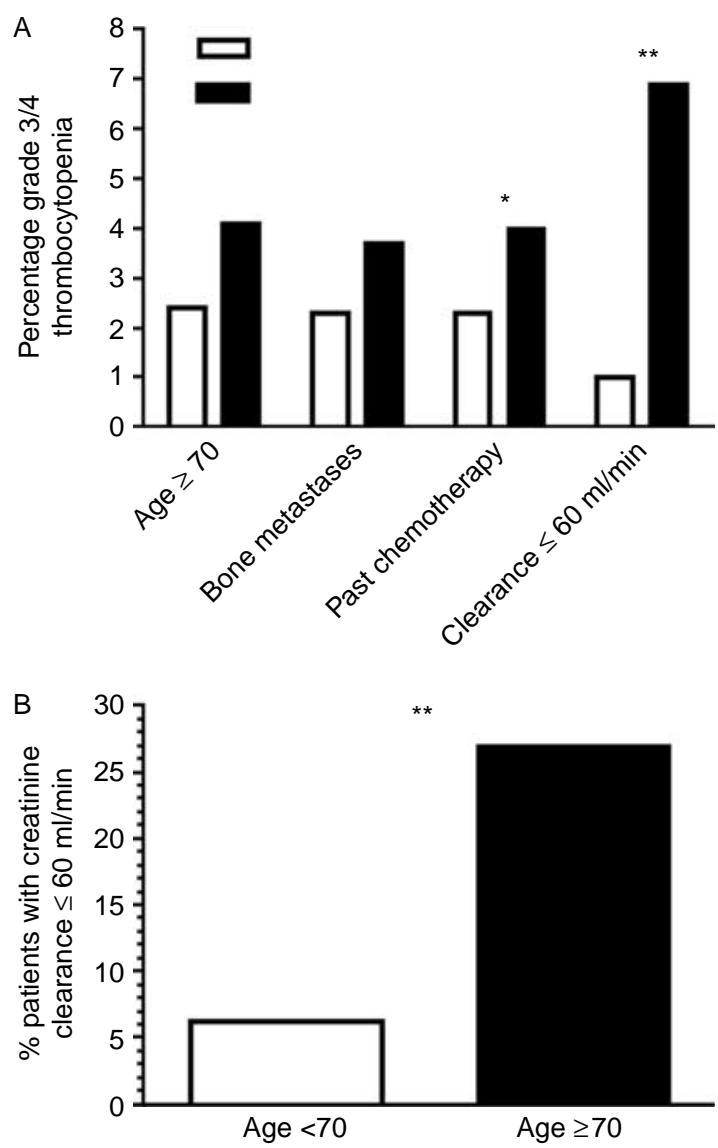

Figure 3 Factors that are associated with a higher frequency of thrombocytopenia (WHO grade 3 or 4 toxicity) after treatment with [ ${ }^{177}$ Lu-DOTA ${ }^{0}$, Tyr $^{3}$ ]octreotate. ${ }^{\star} P<0.05 ;{ }^{\star \star} P<0.001$, logistic regression (upper panel). Low creatinine clearance at start of treatment was more frequent in older age (lower panel, $P<0.001, \chi^{2}$ test). Open bars, factor not present; closed bars, factor present (Data adapted with permission from Kwekkeboom et al. (2008) copyright 2008 American Society of Clinical Oncology. All rights reserved). 


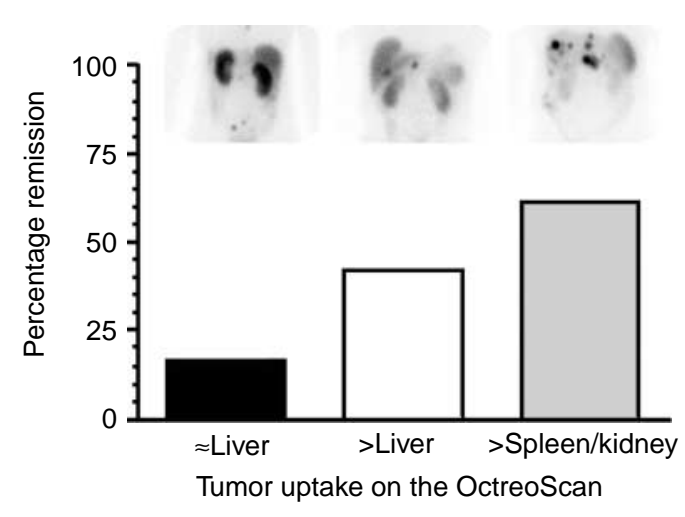

Figure 4 Relationship between the chances of achieving a tumor remission (MR, $\mathrm{PR}$, or $\mathrm{CR}$ ) after treatment with $\left[{ }^{177} \mathrm{Lu}\right.$-DOTA $\left.{ }^{0}, \mathrm{Tyr}^{3}\right]$ octreotate and visually scored tumor uptake on the pretherapeutic OctreoScan. Examples of uptake scores are indicated (Data adapted with permission from Kwekkeboom et al. (2008) copyright 2008 American Society of Clinical Oncology. All rights reserved).

Serious delayed toxicities were observed in 9 out of 504 patients. There were two cases of renal insufficiency, both of which were probably unrelated to ${ }^{177} \mathrm{Lu}$-octreotate treatment. Serious liver toxicity occurred in three patients, and was probably treatment related in two of them. Lastly, MDS occurred in four patients, and was potentially treatment related in three patients.

Treatment responses according to tumor type at 3 months after the last therapy cycle were analyzed in 310 patients. Overall, objective tumor response rate, comprising CR, PR, and MR, was 46\%. Prognostic factors for predicting tumor remission (CR, PR, or MR) as treatment outcome were uptake on the OctreoScan $(P<0.01$; Fig. 4), and Karnofsky Performance Score (KPS) $>70(P<0.05)$.
A small percentage of patients who had either SD or MR at their first two evaluations after therapy had a further improvement in categorized tumor response at 6 months and 12 months of follow-up, occurring in $4 \%$ of patients and $5 \%$ of patients respectively (Figs 5 and 6).

Three of four patients with clinically nonfunctioning neuroendocrine pancreatic tumors that were judged inoperable before treatment with ${ }^{177} \mathrm{Lu}$-octreotate, and who had PR, were succesfully operated 6-12 months after their last treatment, whereas one died of postoperative complications.

Median time to progression was 40 months from start of treatment. Median overall survival (OS) in our 310 GEP tumor patients was 46 months (median follow-up 19 months; 101 deaths). Median diseaserelated survival was $>48$ months (median follow-up 18 months; 81 deaths). Median progression-free survival was 33 months. The most important factor predicting survival was treatment outcome. Low KPS and liver involvement were also very significant predicting factors.

\section{Quality of life}

Another study evaluated the quality of life (QoL) in our first 50 Dutch patients with metastatic somatostatin receptor-positive GEP tumors treated with $\left[{ }^{177} \mathrm{Lu}\right.$ DOTA $^{0}$, Tyr $^{3}$ ]octreotate (Teunissen et al. 2004). The patients completed the European Organization for the Research and Treatment of Cancer QoL Questionnaire C30 (Aaronson et al. 1993) before therapy and at follow-up visit 6 weeks after the last cycle. A significant improvement in the global health status/
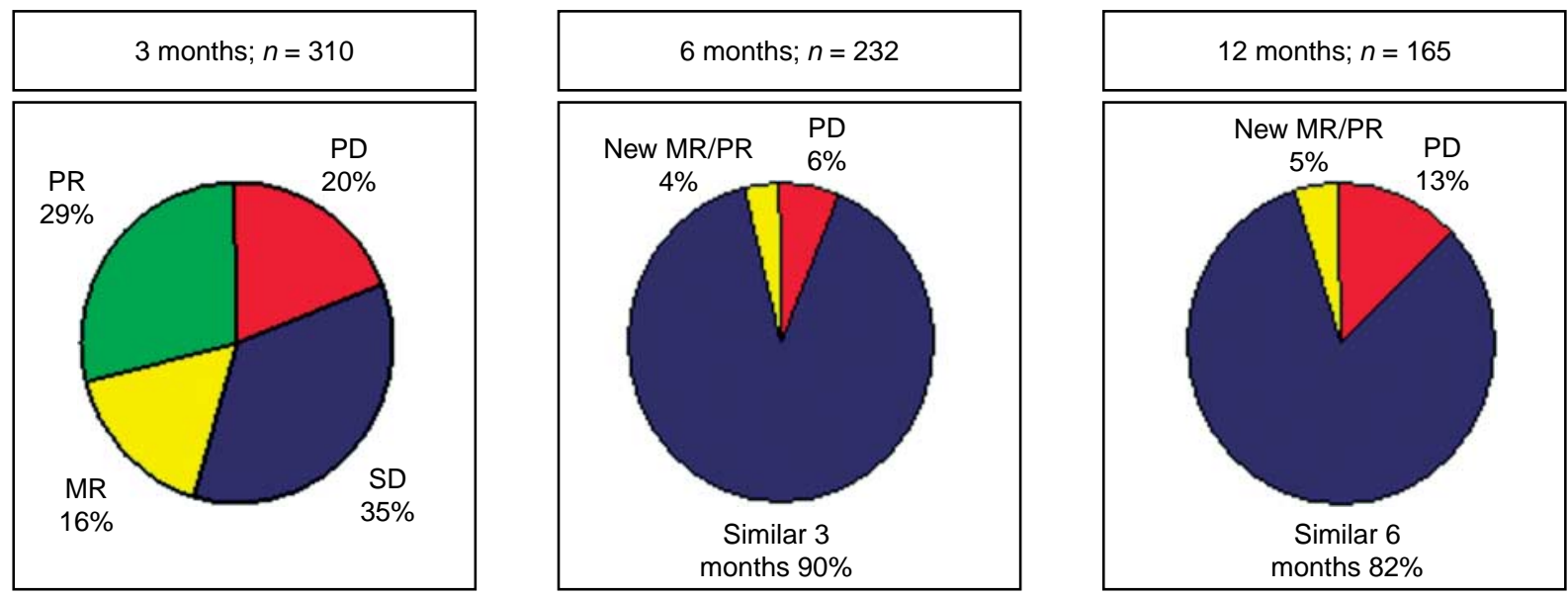

Figure 5 Treatment outcome changes during follow-up. Patient numbers are indicated and decrease due to loss of patients who have PD and because of variable follow-up. There is a small but important percentage of patients who continue to have CT-assessed tumor shrinkage during prolonged follow-up (yellow pie parts). 

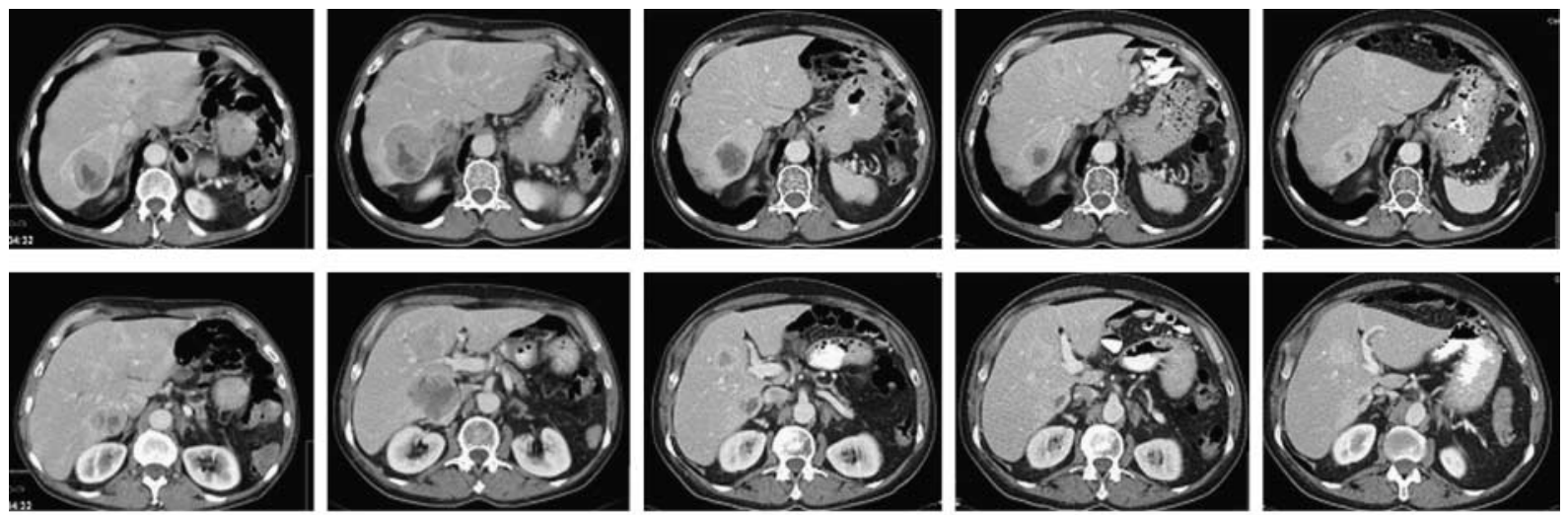

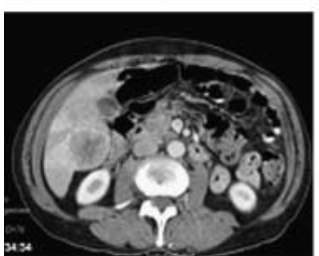

A

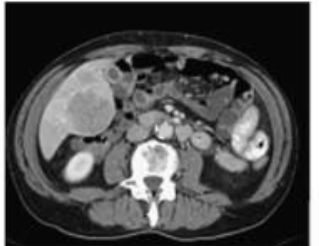

B

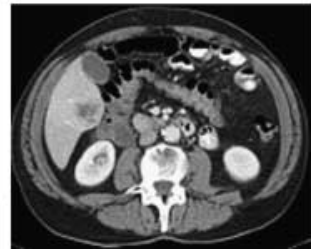

C

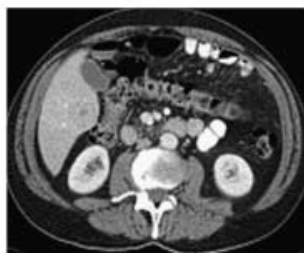

D

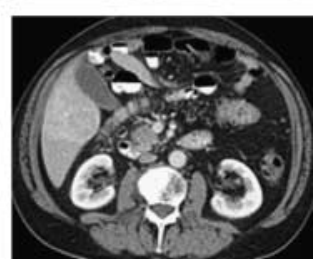

$\mathrm{E}$

Figure 6 Serial CT scans with identical tumor sites in the liver in a patient with metastatic pancreatic neuroendocrine tumor.

(A) Three months before start of therapy. (B) Before start of therapy. PD compared to A. (C) Six weeks after the last therapy cycle: tumor regression (PR). (D) Three months after the last therapy cycle: further regression. (E) Six months after the last therapy cycle: ongoing tumor regression.

QoL scale was observed after therapy with $\left[{ }^{177} \mathrm{Lu}-\right.$ DOTA $^{0}$, Tyr $^{3}$ ]octreotate. Furthermore, significant improvement was observed in the role, emotional, and social function scales. The symptom scores for fatigue, insomnia, and pain decreased significantly. Patients with proven tumor regression most frequently had an improvement of QoL domains. However, because of the lack of a control group in this study, some placebo effect cannot be ruled out completely.

\section{Comparison of treatment with $\left[{ }^{177}\right.$ Lu-DOTA ${ }^{0}$, Tyr $^{3}$ ]octreotate with other PRRT}

Treatment with radiolabeled somatostatin analogs is a promising new tool in the management of patients with inoperable or metastasized neuroendocrine tumors. The results that were obtained with $\left[{ }^{90} \mathrm{Y}\right.$-DOTA $\left.{ }^{0}, \mathrm{Tyr}^{3}\right]$ octreotide and $\left[{ }^{177} \mathrm{Lu}-D O T A^{0}, \mathrm{Tyr}^{3}\right]$ octreotate are very encouraging, although a direct, randomized comparison between the various treatments is lacking. Also, the reported percentages of tumor remission after $\left[{ }^{90} \mathrm{Y}_{\text {-DOTA }}{ }^{0}, \mathrm{Tyr}^{3}\right]$ octreotide treatment vary. This may have several causes: the administered doses and dosing schemes differ: some studies use dose-escalating schemes, whereas others use fixed doses; also, there are several patient and tumor characteristics that determine treatment outcome, such as amount of uptake on the OctreoScan, the estimated total tumor burden, and the extent of liver involvement. Therefore, differences in patient selection may play an important role in determining treatment outcome. Other factors that can have contributed to the different results that were found in the different centers performing trials with the same compounds may be differences in tumor response criteria, and centralized versus decentralized follow-up CT scoring.

From our analysis in patients treated with $\left[{ }^{177} \mathrm{Lu}-\mathrm{DOTA}{ }^{0}, \mathrm{Tyr}^{3}\right]$ octreotate, we learned that the two significant factors predicting favorable treatment outcome were high patient performance score and high uptake on the pretreatment OctreoScan. It is obvious that different studies can only be reliably compared if stratification for these factors is applied. From the published data, such stratified comparison cannot be performed. Also, in order to establish which treatment scheme and which radiolabeled somatostatin analogs or combination of analogs is optimal, randomized trials are needed.

Chelated lanreotide, another somatostatin analog, labeled with ${ }^{111}$ In for diagnostic purposes and with ${ }^{90} \mathrm{Y}$ for therapeutic use has been advocated because of its better binding than $\left[{ }^{111}\right.$ In-DTPA $\left.{ }^{0}\right]$ octreotide to the somatostatin receptor subtypes 3 and 4 (Virgolini et al. 2002). This claim can be questioned (Reubi et al. 2000). Although this compound has been used to treat patients with GEP tumors, it shows poorer affinity than 
radiolabeled $\left[\mathrm{DOTA}^{0}, \mathrm{Tyr}^{3}\right.$ ] octreotide/octreotate for the somatostatin receptor subtype-2, which is predominantly overexpressed in GEP tumors (Reubi et al. 2000; Table 6).

Wehrmann et al. (2007) compared the biodistribution of $\left[{ }^{177}\right.$ Lu-DOTA $\left.{ }^{0}\right]$ octreotate and $\left[{ }^{177}\right.$ Lu-DOTA, 1naphtylalanin $\left.{ }^{3}\right]$ octreotide $\left[{ }^{177}\right.$ Lu-DOTA $\left.^{0}\right]$ NOC in patients, and concluded that tumor uptake and absorbed dose were comparable for both radioligands, whereas whole-body retention was lower for $\left[{ }^{177} \mathrm{Lu}-\mathrm{DOTA}{ }^{0}\right]$ octreotate, and therefore the authors advocate the use of $\left[{ }^{177} \mathrm{Lu}-\mathrm{DOTA}{ }^{0}\right]$ octreotate.

Preliminary data have been presented of a study using ${ }^{90} \mathrm{Y}$-labeled [DOTA ${ }^{0}, \mathrm{Tyr}^{3}$ ] octreotate (Baum et al. 2004a,b). However, the treatment protocols vary and the way of response evaluation was not clearly defined. The reported results were an objective response rate (PR) of 37\% (28/75) and a stabilization of the disease in $39 / 75$ patients (52\%). In the same study, the intra-arterial use of $\left[{ }^{90} \mathrm{Y}\right.$-DOTA $\left.{ }^{0}, \mathrm{Tyr}^{3}\right]$ octreotate in five patients was described. However, no detailed results for this application were provided. An important issue is that to date reliable dosimetry for $\left[{ }^{90} \mathrm{Y}\right.$-DOTA $\left.{ }^{0}, \mathrm{Tyr}^{3}\right]$ octreotate is lacking.

\section{Comparison of survival data}

Because the treatment with $\left[{ }^{177} \mathrm{Lu}-\mathrm{DOTA}^{0}, \mathrm{Tyr}^{3}\right]-$ octreotate is still open for new patients, and median follow-up in relation to survival is relatively short, we also analyzed our local, Dutch patients separately with subgroups that had longer follow-up. The results from these analyses point out that both overall and disease-specific survival time are consistently at or above 48 months. These numbers compare favorably to those reported in the literature. Clancy et al. (2006) reported a significantly shorter survival in patients with elevated serum alkaline phosphatase concentrations at referral compared to those who had normal values. We found the same, but in our patients treated with ${ }^{177} \mathrm{Lu}$-octreotate, survival from referral was longer. Even more striking was the difference in median OS from diagnosis: 128 vs 72 months, despite the fact that in our group mean serum alkaline phosphatase concentration was higher, indicating more advanced liver involvement and worse prognosis (Fig. 7). Comparing survival data in our group, either from time of diagnosis or from time of referral, with data from different epidemiologic studies or studies pertaining to a specific intervention, and limiting our data to similar subgroups of patients, we found a benefit in OS for patients treated with ${ }^{177} \mathrm{Lu}$-octreotate, which ranged

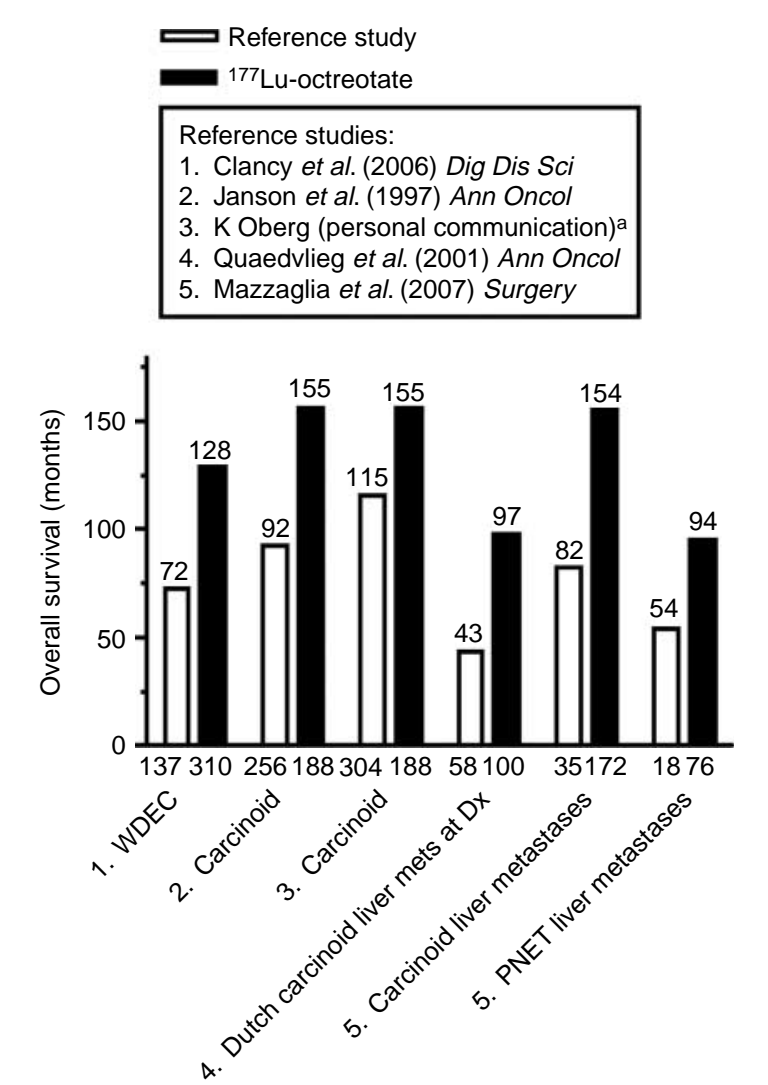

Figure 7 Overall, survival in months since diagnosis in patients from observational and interventional studies (blue bars) and in similar patients with regard to tumor type and disease stage treated with $\left[{ }^{177} \mathrm{Lu}\right.$-DOTA $\left.{ }^{0}, \mathrm{Tyr}^{3}\right]$ octreotate (red bars). There is a survival benefit of 40-72 months in patients treated with ${ }^{177} \mathrm{Lu}^{1}$-DOTA $\left.{ }^{0}, \mathrm{Tyr}^{3}\right]$ octreotate (Data adapted with permission from Kwekkeboom et al. (2008) copyright 2008 American Society of Clinical Oncology. All rights reserved). Dx, diagnosis; WDEC, well-differentiated endocrine carcinoma; PNET, pancreatic neuroendocrine tumor. ${ }^{\mathrm{a}} \mathrm{K}$ Oberg and D J Kwekkeboom, personal communication.

from 40 to 72 months from diagnosis (Fig. 7). We are aware that comparisons with historical controls should be interpreted with caution, but we also think that such a consistent difference with many other reports in similar patient groups cannot be ignored, and it is most probably caused by a real difference in survival.

\section{Comparison with chemotherapy}

In order to better evaluate the response to PRRT, it would have been preferable that a randomized trial was performed comparing PRRT to no further treatment at all. This however, is presently no longer possible, since patients can be treated with PRRT in several medical centers and since the results of such treatment are so impressive that withholding it to half 
of the patients in an experimental setting cannot be ethically justified. However, Faiss et al. (2003) reported tumor remissions in 4 out of 80 (5\%) GEP tumor patients who had progressive disease at study entry and were treated with somatostatin analogs and/or interferon- $\alpha$. By contrast, we found tumor remissions in $46 \%$ of our patients who were treated with ${ }^{177} \mathrm{Lu}$-octreotate, whether or not they had PD at study entry (Kwekkeboom et al. 2008). It seems highly unlikely that such a difference could have been caused by patient selection.

Apart from the proportion of patients with a tumor remission, the duration of such a response is another important treatment outcome parameter. Reported response rates for single agent and combination chemotherapy in patients with GEPNETs are for instance as high as $40-60 \%$ for well-differentiated pancreatic tumors and poorly differentiated tumors from any origin, whereas success rates for midgut tumors rarely exceed 20\% in recent studies (Bukowski et al. 1994, Andreyev et al. 1995, Neijt et al. 1995, Ritzel et al. 1995, Cheng \& Saltz 1999, Ansell et al. 2001; Table 7), for a review see O'Toole et al. (2004). High response rates have been reported in older series (Moertel et al. 1980, 1992, Moertel 1983), but in these studies the response evaluation also included biochemical responses (changes in serum tumor marker levels) as well as physical examination for the evaluation of hepatomegaly. Indeed, much of the discrepancy between older and more recent studies can be ascribed to differences in response criteria, as is illustrated in a more recent study by Cheng \& Saltz (1999) who described that their percentage of patients with an objective response would have increased from 6 to $25 \%$ if they had accepted not only measured CT scan changes as response criteria, but also decreases of hepatomegaly assessed with physical examination. Despite the varying percentages of objective responses that have been reported for chemotherapy, the median time to progression in most of the studies is $<18$ months. In this respect, treatment with ${ }^{90} \mathrm{Y}$-octreotide or ${ }^{177} \mathrm{Lu}$-octreotate performs considerably better with a median time to progression of 30 and 40 months respectively (Valkema et al. 2003, Kwekkeboom et al. 2008).

Not only response rate, but also the duration of the response, progression-free survival, and OS are more favorable after ${ }^{177} \mathrm{Lu}$-octreotate treatment than in recent reports on chemotherapy (Table 7).

\section{Novel drugs}

Multiple new drugs are under investigation in patients with GEPNETs. The combination of capecitabine (Xeloda, an oral pro-drug of 5-fluorouracil (5-FU)) and temozolomide (Temodal, Temodar, an oral alkalyting agent) resulted in PR in 12 of 17 patients, and SD in 5. After a median time of follow-up of 12 months, none of the patients had developed progression (Strosberg et al. 2008).

As neuroendocrine tumors are highly vascularized, several drugs that inhibit angiogenesis are studied. Effects of bevacizumab (Avastin, Hoffmann la Roche AG, Grenzach-Wyhlen, Germany) with temozolomide were studied in 29 patients and resulted in a PR in $14 \%$ and SD in 79\% (Kulke et al. 2006). Seven of 41 (17\%) evaluable patients with metastasized carcinoid who

Table 7 Results of recent chemotherapy reports compared to treatment with $\left[{ }^{177}\right.$ Lu-DOTA $^{0}$, Tyr $\left.^{3}\right]$ octreotate

\begin{tabular}{|c|c|c|c|c|c|c|}
\hline Regimen & $\begin{array}{l}\text { Tumor } \\
\text { types }\end{array}$ & $\begin{array}{l}\text { Patient } \\
\text { number }\end{array}$ & $\begin{array}{c}\text { PR/CR } \\
(\%)\end{array}$ & $\begin{array}{l}\text { Median } \\
\text { PFS (mo) }\end{array}$ & $\begin{array}{l}\text { Median } \\
\text { OS (mo) }\end{array}$ & Study (year) \\
\hline STZ+ doxorubicin & PNET & 16 & 6 & NA & NA & Cheng \& Saltz (1999) \\
\hline Dacarbazine & Carc & 56 & 16 & NA & 20 & Bukowski et al. (1994) \\
\hline Dacarbazine & Carc & 7 & 14 & NA & NA & Ritzel et al. (1995) \\
\hline$F U+I F-A$ & Carc/PNET & 24 & 21 & 8 & 23 & Andreyev et al. (1995) \\
\hline Mitoxantrone & Carc/PNET & 30 & 7 & NA & 16 & Neijt et al. (1995) \\
\hline Paclixatel & Carc/PNET & 24 & 4 & 3 & 18 & Ansell et al. (2001) \\
\hline $\mathrm{STZ}+\mathrm{FU}+$ doxorubicin & PNET & 84 & 39 & 18 & 37 & Kouvaraki et al. (2004) \\
\hline Doxorubicin +FU & Carc & 85 & 13 & 5 & 16 & Sun et al. (2005) \\
\hline $\mathrm{STZ}+\mathrm{FU}$ & Carc & 78 & 15 & 5 & 24 & Sun et al. (2005) \\
\hline Irinotecan + FU & Carc/PNET & 20 & 5 & 5 & 15 & Ducreux et al. (2006) \\
\hline Oxaliplatin + capecitabine & $\begin{array}{l}\text { Well-differentiated } \\
\text { NET }\end{array}$ & 27 & 30 & NA & 40 & Bajetta et al. (2007) \\
\hline${ }^{177}$ Lu-octreotate & Carc/PNET & 310 & 30 & 32 & 46 & Kwekkeboom et al. (2008) \\
\hline
\end{tabular}

STZ, streptozotocin; FU, 5-fluorouracil; IF-A, interferon- $\alpha$; PNET, pancreatic neuroendocrine tumor; Carc, carcinoid; PFS, progression-free survival; OS, overall survival; NA, not available (adapted with permission from Kwekkeboom et al. (2008) copyright 2008 American Society of Clinical Oncology. All rights reserved). 
were treated with sorafenib (Nexavar) had MR or PR, and $8 / 20$ patients had a progression-free survival of $>6$ months. Thirteen of 41 evaluable patients (32\%) with a pancreatic NET had MR or PR and progressionfree survival was $>6$ months in $14 / 23$ patients (Hobday et al. 2007). Yao et al. (2007) reported their results of treatment with imatinib in advanced carcinoid tumors: one out of 27 patients had PR and 17 had SD. Median progression-free survival was 5.5 months.

Sunitinib (SU11248, Sutent), an oral, multitargeted tyrosine kinase inhibitor, has also been tested in patients with GEPNETs. In a phase II study, 11 of 66 patients (17\%) with pancreatic NET had PR and 45 had SD. In patients with carcinoids, sunitinib treatment resulted in PR in 1 of 41 patients and SD in 34. Overall, median time to progression was 8 months in pancreatic NET and 10 months in carcinoids. (Kulke et al. 2008).

Recently, inhibitors of the mammalian target of rapamycin were introduced in studies for treating patients with GEPNETs. Therapy with temsirolimus (Torisel, Pfizer, NY, USA) as single agent had limited anti-tumor activity (Duran et al. 2006). Everolimus
(RAD001, Certican) in combination with long-acting octreotide seems to have more promising anti-tumor effects. Sixty patients of whom 39 had PD at study entry were treated: $17 \%$ had PR and $75 \%$ had SD. The median progression free survival was 14 months (Yao et al. 2008). However, some of these studies present preliminary data, reported as congress abstracts, and full reports or confirmatory studies have to be awaited.

\section{Timing of treatment}

In patients treated with $\left[{ }^{177} \mathrm{Lu}\right.$-DOTA $\left.^{0}, \mathrm{Tyr}^{3}\right]$ octreotate, median OS was shorter in patients having a poor performance score and those having extensive liver involvement. This implies that treatment with $\left[{ }^{177} \mathrm{Lu}-\mathrm{DOTA}{ }^{0}, \mathrm{Tyr}^{3}\right]$ octreotate should preferably be started early in the disease evolution. Because GEPNETs can be clinically stable for years; however, it is, in our opinion, good clinical practice to wait for signs of disease progression if the tumor load is moderate. Such signs should not be restricted to CT-assessed tumor growth, but also include rises in serum tumor markers, increase in symptoms, or

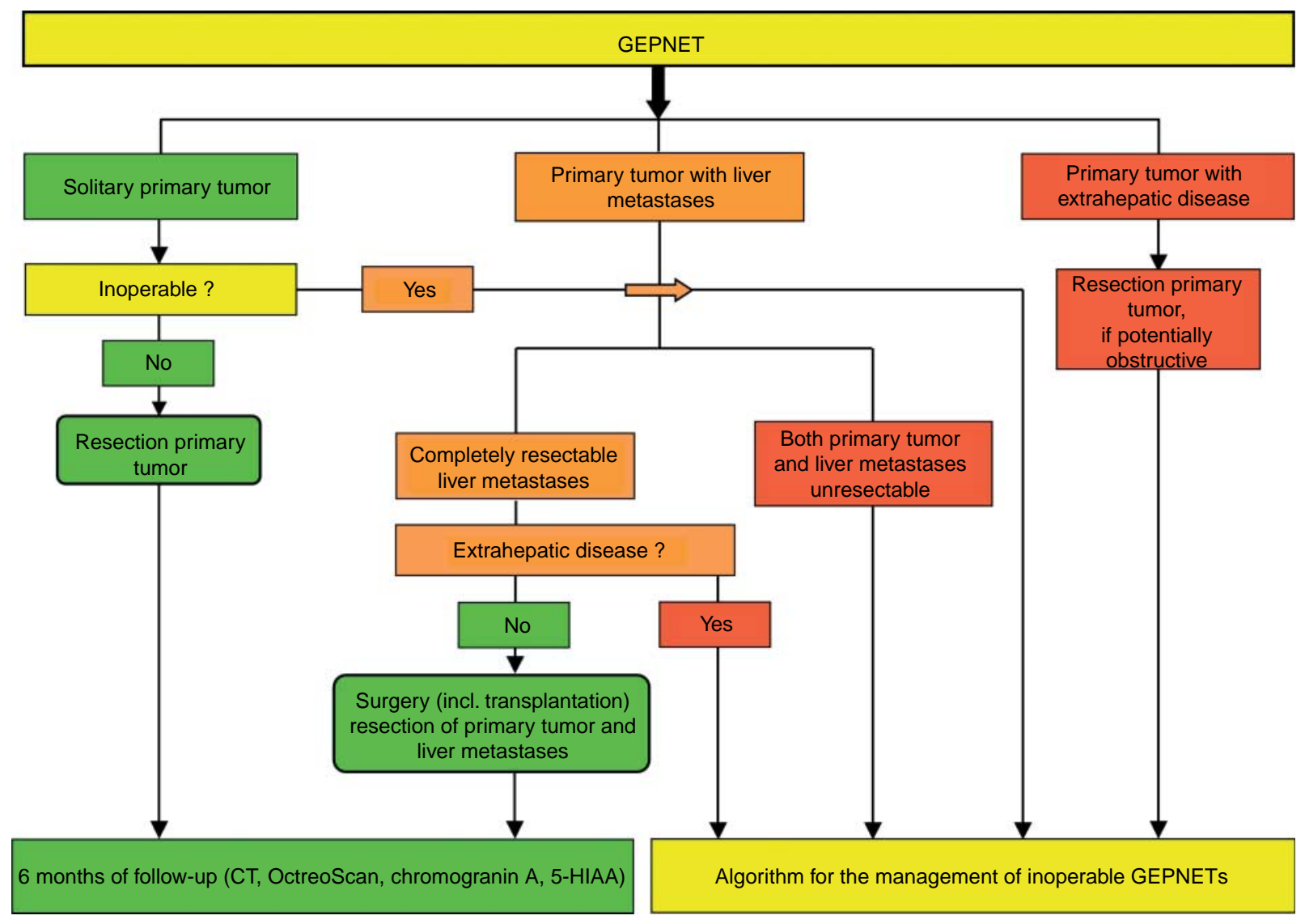

Figure 8 Algorithm for the treatment of patients with GEPNETs. 


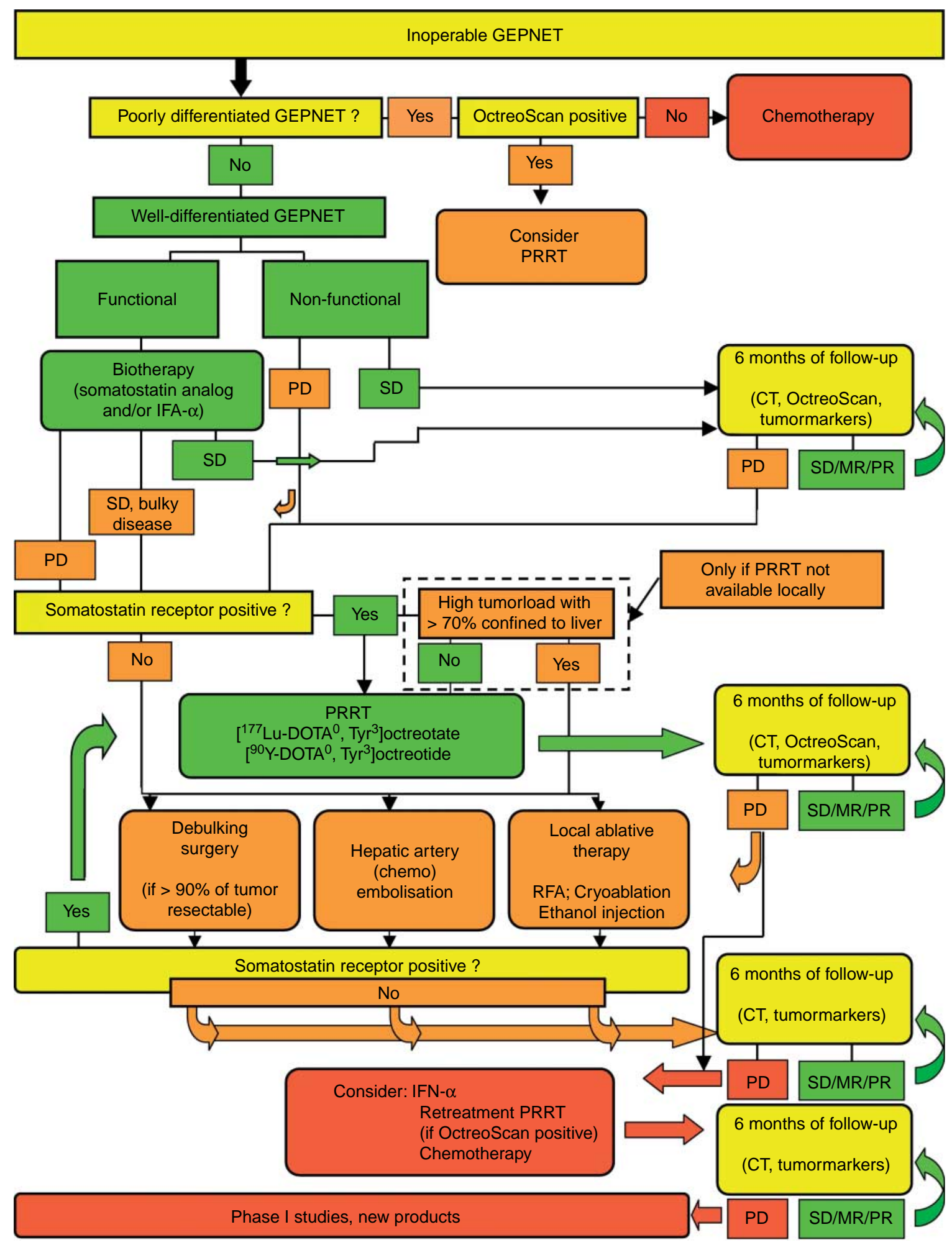

Figure 9 Algorithm for the treatment of patients with inoperable and/or metastasized GEPNETs. IFN-a, interferon- $\alpha$; RFA, radio frequency ablation. 
involuntary weight loss. In patients with very limited tumor load and in whom cure is potentially possible, treatment should be initiated without further delay, and the same holds true for patients with extensive tumor load, hepatomegaly, or those with significant weight loss, when waiting for formally assessed tumor progression would place these patients in an unfavorable starting position for treatment or would even qualify them as ineligible.

\section{Options to improve PRRT}

From animal experiments, it can be inferred that ${ }^{90}$ Y-labeled somatostatin analogs may be more effective for larger tumors, whereas ${ }^{177} \mathrm{Lu}$-labeled somatostatin analogs may be more effective for smaller tumors, but their combination may be the most effective (De Jong et al. 2002). Therefore, apart from comparisons between radiolabeled octreotate and octreotide, and between somatostatin analogs labeled with ${ }^{90} \mathrm{Y}$ or ${ }^{177} \mathrm{Lu}$, PRRT with combinations of ${ }^{90} \mathrm{Y}$ and ${ }^{177} \mathrm{Lu}$-labeled analogs should also be evaluated.

Future directions to improve this therapy may also include the use of radiosensitizing chemotherapeutical agents. Chemosensitization with 5-FU in combination with ${ }^{90} \mathrm{Y}$-labeled antibody radioimmunotherapy is feasible and safe (Wong et al. 2003). Also, chemosentization with 5-FU, combined with $\left[{ }^{111}\right.$ In-DTPA $]$ octreotide treatment resulted in symptomatic response in $71 \%$ of patients with neuroendocrine tumors (Kong et al. 2005), whereas other studies using only $\left[{ }^{111}\right.$ In-DTPA $]$ octreotide treatment reported such responses in lower percentages (Anthony et al. 2002, Valkema et al. 2002). Numerous trials to the effects of combined chemotherapy and (fractionated) external beam radiotherapy have been performed. In many of these, 5-FU was used. More recent trials used the prodrug of 5-FU, capecitabine, which has the advantage of oral administration. Also with the combination of radiotherapy and capecitabine, an increased efficacy in terms of tumor growth control was reported if compared to radiotherapy as single treatment modality (Rich et al. 2004). If capecitabine is used in relatively low doses $\left(1600-2000 \mathrm{mg} / \mathrm{m}^{2}\right.$ per day), grade 3 hematologic or other toxicity is rare (Dunst et al. 2002, Rich et al. 2004). For these reasons, after proving the safety of the combined therapy (Van Essen et al. 2008), we started a randomized multicenter trial comparing treatment with ${ }^{177} \mathrm{Lu}$-octreotate with and without capecitabine in patients with GEPNETs.

Also, attempts to improve the results of this type of therapy may focus on further reducing the radiation absorbed dose to normal tissues and organs, like kidneys and bone marrow, or at increasing the receptor density on the tumors, for instance via receptor upregulation. Both strategies may increase the therapeutic window.

Lastly, individualized dosimetry for each patient is desirable. Both kidney absorbed dose and bone marrow absorbed radiation dose vary widely between patients (Kwekkeboom et al. 2001, Förrer et al. 2009). This means that with fixed-dose regimens that show relatively few side effects, a proportion of patients is undertreated. Tailored dosimetry, currently based on urine collection, repeated imaging and blood sampling after therapy, is time consuming. However, such an individualized calculation of the maximum cumulative doses that can be given to a certain patient may in a considerable part of the patients result in higher cumulative doses that can safely be administered. Improvements in methods as well as consensus on standards for dosimetry would greatly stimulate the clinical acceptance of individualized dosimetry.

\section{Place of PRRT in the treatment of patients with GEPNETs}

The place and role that treatment with $\left[{ }^{177} \mathrm{Lu}-\right.$ DOTA ${ }^{0}$, Tyr $\left.^{3}\right]$ octreotate or $\left[{ }^{90} \mathrm{Y}^{-D O T A}{ }^{0}, \mathrm{Tyr}^{3}\right]$ octreotide has in the management of patients with inoperable or metastasized GEPNETs, according to our clinical practice, is outlined in Figs 8 and 9. These are flow schemes that summarize the treatment options and the clinical decision making in such patients.

\section{Conclusions}

SRI with $\left[{ }^{111}\right.$ In-DTPA $\left.{ }^{0}\right]$ octreotide has proven its role in the diagnosis and staging of GEPNETs. Newer radiolabeled somatostatin analogs which can be used in PET imaging, and which have a higher affinity for the somatostatin receptor, especially receptor subtype-2, have been developed. It would be desirable, however, if one radiolabeled analog became the new standard for PET imaging, because the current application of a multitude of analogs implies a fragmented knowledge on the interpretation of the images that are obtained in clinical practice. In our view, the most likely candidates for such a universal PET tracer for SRI are $\left[{ }^{68} \mathrm{Ga}-\mathrm{DOTA}{ }^{0}, \mathrm{Tyr}^{3}\right]$ octreotate or $\left[{ }^{68} \mathrm{Ga}-\mathrm{DOTA}^{0}\right.$, $\mathrm{Tyr}^{3}$ ]octreotide.

Treatment with radiolabeled somatostatin analogs is a promising new tool in the management of patients with inoperable or metastasized neuroendocrine tumors. Symptomatic improvement may occur with all ${ }^{111} \mathrm{In}-,{ }^{90} \mathrm{Y}-$, or ${ }^{177} \mathrm{Lu}$-labeled somatostatin analogs 
that have been used for PRRT. The results that were obtained with $\left[{ }^{90} \mathrm{Y}\right.$-DOTA $\left.{ }^{0}, \mathrm{Tyr}^{3}\right]$ octreotide and $\left[{ }^{177} \mathrm{Lu}-\mathrm{DOTA}{ }^{0}, \mathrm{Tyr}^{3}\right]$ octreotate are very encouraging in terms of tumor regression. Also, if kidney protective agents are used, the side effects of this therapy are few and mild, and the duration of the therapy response for both radiopharmaceuticals is more than 30 months. The patients' self-assessed QoL increases significantly after treatment with $\left[{ }^{177} \mathrm{Lu}-\mathrm{DOTA}{ }^{0}, \mathrm{Tyr}^{3}\right]$ octreotate. Lastly, compared to historical controls, there is a benefit in OS of several years from the time of diagnosis in patients treated with $\left[{ }^{177}\right.$ Lu-DOTA ${ }^{0}$, $\mathrm{Tyr}^{3}$ ]octreotate. These data compare favorably with the limited number of alternative treatment approaches. If more widespread use of PRRT can be guaranteed, such therapy may well become the therapy of first choice in patients with metastasized or inoperable GEPNETs.

\section{Declaration of interest}

Eric Krenning is a member of the advisory board of Biosynthema and Novartis, and a consultant of Biosynthema and Covidien. He receives research or material support from Covidien, Novartis, and Biosynthema, and is a shareholder in Biosynthema. Dik Kwekkeboom is a shareholder in Biosynthema.

\section{Funding}

This research did not receive any specific grant from any funding agency in the public, commercial, or not-for-profit sector.

\section{References}

Aaronson NK, Ahmedzai S, Bergman B, Bullinger M, Cull A, Duez NJ, Filiberti A, Flechtner H, Fleishman SB, de Haes JC et al. 1993 The European Organization for Research and Treatment of Cancer QLQ-C30: a quality-of-life instrument for use in international clinical trials in oncology. Journal of the National Cancer Institute $\mathbf{8 5}$ 365-376.

Adams S, Baum RP, Hertel A, Schumm-Draeger PM, Usadel KH \& Hör G 1998 Comparison of metabolic and receptor imaging in recurrent medullary thyroid carcinoma with histopathological findings. European Journal of Nuclear Medicine 25 1277-1283.

Ahlman H, Wängberg B, Tisell LE, Nilsson O, Fjälling M \& Forssell-Aronsson E 1994 Clinical efficacy of octreotide scintigraphy in patients with midgut carcinoid tumours and evaluation of intraoperative scintillation detection. British Journal of Surgery 81 1144-1149.

Ambrosini V, Tomassetti P, Castellucci P, Campana D, Montini G, Rubello D, Nanni C, Rizzello A, Franchi R \& Fanti S 2008 Comparison between ${ }^{68}$ Ga-DOTA-NOC and
${ }^{18}$ F-DOPA PET for the detection of gastro-enteropancreatic and lung neuro-endocrine tumours. European Journal of Nuclear Medicine and Molecular Imaging 35 1431-1438.

Andreyev HJ, Scott-Mackie P, Cunningham D, Nicolson V, Norman AR, Badve SS, Iveson A \& Nicolson MC 1995

Phase II study of continuous infusion fluorouracil and interferon alfa-2b in the palliation of malignant neuroendocrine tumors. Journal of Clinical Oncology 13 1486-1492.

Ansell SM, Pitot HC, Burch PA, Kvols LK, Mahoney MR \& Rubin J 2001 A phase II study of high-dose paclitaxel in patients with advanced neuroendocrine tumors. Cancer 91 1543-1548.

Anthony LB, Woltering EA, Espanan GD, Cronin MD, Maloney TJ \& McCarthy KE 2002 Indium-111pentetreotide prolongs survival in gastroenteropancreatic malignancies. Seminars in Nuclear Medicine 32 123-132.

Arnold R, Benning R, Neuhaus C, Rolwage M \& Trautmann ME 1993 Gastroenteropancreatic endocrine tumours: effect of Sandostatin on tumour growth. The German Sandostatin Study Group. Digestion 54 (Suppl 1) 72-75.

Bajetta E, Catena L, Procopio G, De Dosso S, Bichisao E, Ferrari L, Martinetti A, Platania M, Verzoni E, Formisano B et al. 2007 Are capecitabine and oxaliplatin (XELOX) suitable treatments for progressing low-grade and highgrade neuroendocrine tumours? Cancer Chemotherapy and Pharmacology 59 637-642.

Balon HR, Goldsmith SJ, Siegel BA, Silberstein EB, Krenning EP, Lang O \& Donohoe KJ 2001 Procedure guideline for somatostatin receptor scintigraphy with ${ }^{111}$ In-pentetreotide. Journal of Nuclear Medicine $\mathbf{4 2}$ 1134-1138.

Baum RP, Soldner J, Schmucking M \& Niesen A $2004 a$ Peptidrezeptorvermittelte radiotherapie (PRRT) neuroendokriner tumoren klinischen indikationen und erfahrung mit 90Yttrium-markierten somatostatinanaloga. Der Onkologe 10 1098-1110.

Baum RP, Soldner J, Schmucking M \& Niesen A $2004 b$ Intravenous and intra-arterial peptide receptor radionuclide therapy (PRRT) using Y-90-DOTA-Tyr ${ }^{3}$ octreotate (Y-90-DOTA-TATE) in patients with metastatic neuroendocrine tumors. European Journal of Nuclear Medicine 31 (Suppl 2) S238 (abstract).

Belhocine T, Foidart J, Rigo P, Najjar F, Thiry A, Quatresooz P \& Hustinx R 2002 Fluorodeoxyglucose positron emission tomography and somatostatin receptor scintigraphy for diagnosing and staging carcinoid tumours: correlations with the pathological indexes p53 and Ki-67. Nuclear Medicine Communications 23 727-734.

Bodei L, Cremonesi M, Zoboli S, Grana C, Bartolomei M, Rocca P, Caracciolo M, Mäcke HR, Chinol M \& Paganelli G 2003 Receptor-mediated radionuclide therapy with ${ }^{90}$ Y-DOTATOC in association with amino acid infusion: a phase I study. European Journal of Nuclear Medicine and Molecular Imaging 30 207-216. 
Bombardieri E, Crippa F, Cataldo I, Chiti A, Seregni E, Soresi E, Boffi R, Invernizzi G \& Buraggi GL 1995 Somatostatin receptor imaging of small cell lung cancer (SCLC) by means of ${ }^{111}$ In-DTPA octreotide scintigraphy. European Journal of Cancer 31A 184-188.

Buchmann I, Henze M, Engelbrecht S, Eisenhut M, Runz A, Schäfer M, Schilling T, Haufe S, Herrmann T \& Haberkorn U 2007 Comparison of ${ }^{68} \mathrm{Ga}$-DOTATOC PET and ${ }^{111}$ In-DTPAOC (Octreoscan) SPECT in patients with neuroendocrine tumours. European Journal of Nuclear Medicine and Molecular Imaging 34 1617-1626.

Bukowski RM, Tangen CM, Peterson RF, Taylor SA, Rinehart JJ, Eyre HJ, Rivkin SE, Fleming TR \& Macdonald JS 1994 Phase II trial of dimethyltriazenoimidazole carboxamide in patients with metastatic carcinoid. Cancer 73 1505-1508.

Bushnell D, O’Dorisio T, Menda Y, Carlisle T, Zehr P, Connolly M, Karwal M, Miller S, Parker S \& Bouterfa H 2003 Evaluating the clinical effectiveness of ${ }^{90} \mathrm{Y}-\mathrm{SMT}$ 487 in patients with neuroendocrine tumors. Journal of Nuclear Medicine 44 1556-1560.

Cheng PN \& Saltz LB 1999 Failure to confirm major objective antitumor activity for streptozocin and doxorubicin in the treatment of patients with advanced islet cell carcinoma. Cancer 86 944-948.

Chinol M, Bodei L, Cremonesi M \& Paganelli G 2002 Receptor-mediated radiotherapy with Y-DOTA-DPheTyr-octreotide: the experience of the European Institute of Oncology group. Seminars in Nuclear Medicine 32 141-147.

Clancy TE, Sengupta TP, Paulus J, Ahmed F, Duh MS \& Kulke MH 2006 Alkaline phosphatase predicts survival in patients with metastatic neuroendocrine tumors. Digestive Diseases and Sciences 51 877-884.

De Jong M, Breeman WA, Bakker WH, Kooij PP, Bernard BF, Hofland LJ, Visser TJ, Srinivasan A, Schmidt MA, Erion JL et al. 1998 Comparison of (111)Inlabeled somatostatin analogues for tumor scintigraphy and radionuclide therapy. Cancer Research 58 437-441.

De Jong M, Valkema R, Jamar F, Kvols LK, Kwekkeboom DJ, Breeman WA, Bakker WH, Smith C, Pauwels S \& Krenning EP 2002 Somatostatin receptor-targeted radionuclide therapy of tumors: preclinical and clinical findings. Seminars in Nuclear Medicine 32 133-140.

De Keizer B, van Aken MO, Feelders RA, de Herder WW, Kam BL, van Essen M, Krenning EP \& Kwekkeboom DJ 2008 Hormonal crises following receptor radionuclide therapy with the radiolabeled somatostatin analogue $\left[{ }^{177} \mathrm{Lu}-\mathrm{DOTA}^{0}, \mathrm{Tyr}^{3}\right]$ octreotate. European Journal of Nuclear Medicine and Molecular Imaging 35 749-755.

De Kerviler E, Cadiot G, Lebtahi R, Faraggi M, Le Guludec D \& Mignon M 1994 Somatostatin receptor cintigraphy in fortyeight patients with the Zollinger-Ellison syndrome. European Journal of Nuclear Medicine 21 1191-1197.

Ducreux M, Ruszniewski P, Chayvialle JA, Blumberg J, Cloarec D, Michel H, Raymond JM, Dupas JL, Gouerou H, Jian R et al. 2000 The antitumoral effect of the long-acting somatostatin analog lanreotide in neuroendocrine tumors. American Journal of Gastroenterology 95 3276-3281.

Ducreux MP, Boige V, Leboulleux S, Malka D, Kergoat P, Dromain C, Elias D, de Baere T, Sabourin JC, Duvillard P et al. 2006 A phase II study of irinotecan with 5-fluorouracil and leucovorin in patients with pretreated gastroenteropancreatic well-differentiated endocrine carcinomas. Oncology 70 134-140.

Duet M, Sauvaget E, Pételle B, Rizzo N, Guichard JP, Wassef M, Le Cloirec J, Herman P \& Tran Ba Huy P 2003 Clinical impact of somatostatin receptor scintigraphy in the management of paragangliomas of the head and neck. Journal of Nuclear Medicine 44 1767-1774.

Dunst J, Reese T, Sutter T, Zühlke H, Hinke A, KöllingSchlebusch K \& Frings S 2002 Phase I trial evaluating the concurrent combination of radiotherapy and capecitabine in rectal cancer. Journal of Clinical Oncology 20 3983-3991.

Duran I, Kortmansky J, Singh D, Hirte H, Kocha W, Goss G, Le L, Oza A, Nicklee T, Ho J et al. 2006 A phase II clinical and pharmacodynamic study of temsirolimus in advanced neuroendocrine carcinomas. British

Journal of Cancer 95 1148-1154.

Erion JL, Bugaj JE, Schmidt MA, Wilhelm RR \& Srinivasan A 1999 High radiotherapeutic efficacy of [Lu-177]DOTA-Y(3)-octreotate in a rat tumor model. Journal of Nuclear Medicine 40 (Suppl) 223P (abstract).

Esser JP, Krenning EP, Teunissen JJ, Kooij PP, van Gameren AL, Bakker WH \& Kwekkeboom DJ 2006 Comparison of [(177)Lu-DOTA(0), Tyr(3)]octreotate and [(177)Lu$\operatorname{DOTA}(0), \operatorname{Tyr}(3)$ ]octreotide: which peptide is preferable for PRRT? European Journal of Nuclear Medicine and Molecular Imaging 33 1346-1351.

Faiss S, Pape UF, Bohmig M, Dörffel Y, Mansmann U, Golder W, Riecken EO, Wiedenmann B \& International Lanreotide and Interferon Alfa Study Group 2003 Prospective, randomized, multicenter trial on the antiproliferative effect of lanreotide, interferon alfa, and their combination for therapy of metastatic neuroendocrine gastroenteropancreatic tumors - the International Lanreotide and Interferon Alfa Study Group. Journal of Clinical Oncology 21 2689-2696.

Fanti S, Ambrosini V, Tomassetti P, Castellucci P, Montini G, Allegri V, Grassetto G, Rubello D, Nanni C \& Franchi R 2008 Evaluation of unusual neuroendocrine tumours by means of ${ }^{68} \mathrm{Ga}$-DOTA-NOC PET. Biomedicine and Pharmacotherapy 62 667-671.

Förrer F, Krenning EP, Kooij PP, Bernard BF, Konijnenberg M, Bakker WH, Teunissen JJ, de Jong M, van Lom K, de Herder WW et al. 2009 Bone marrow dosimetry in peptide receptor radionuclide therapy with [(177)LuDOTA(0), Tyr(3)]octreotate. European Journal of Nuclear Medicine and Molecular Imaging (Epub ahead of print).

Gabriel M, Decristoforo C, Kendler D, Dobrozemsky G, Heute D, Uprimny C, Kovacs P, Von Guggenberg E, Bale 
R \& Virgolini IJ $2007{ }^{68}$ Ga-DOTA-Tyr ${ }^{3}$-octreotide PET, in neuroendocrine tumors: comparison with somatostatin receptor scintigraphy and CT. Journal of Nuclear Medicine 48 508-518.

Gibril F, Reynolds JC, Doppman JL, Chen CC, Venzon DJ, Termanini B, Weber HC, Stewart CA \& Jensen RT 1996 Somatostatin receptor scintigraphy: its sensitivity compared with that of other imaging methods in detecting primary and metastatic gastrinomas. A prospective study. Annals of Internal Medicine 125 26-34.

Gibril F, Reynolds JC, Chen CC, Yu F, Goebel SU, Serrano J, Doppman JL \& Jensen RT 1999 Specificity of somatostatin receptor scintigraphy: a prospective study and effects of false-positive localizations on management in patients with gastrinomas. Journal of Nuclear Medicine 40 539-553.

Gulec SA, Serafini AN, Sridhar KS, Peker KR, Gupta A, Goodwin WJ, Sfakianakis GN \& Moffat FL 1998 Somatostatin receptor expression in Hurthle cell cancer of the thyroid. Journal of Nuclear Medicine 39 243-245.

Haldemann AR, Rosler H, Barth A, Waser B, Geiger L, Godoy N, Markwalder RV, Seiler RW, Sulzer M \& Reubi JC 1995 Somatostatin receptor scintigraphy in central nervous system tumors: role of blood-brain barrier permeability. Journal of Nuclear Medicine 36 403-410.

Haslinghuis LM, Krenning EP, de Herder WW, Reijs AEM \& Kwekkeboom DJ 2001 Somatostatin receptor scintigraphy in the follow-up of patients with differentiated thyroid cancer. Journal of Endocrinological Investigation 24 415-422.

Hobday TJ, Rubin J, Holen K, Picus J, Donehower R, Marschke R, Maples W, Lloyd R, Mahoney M \& Erlichman C 2007 MC044h, a phase II trial of sorafenib in patients (pts) with metastatic neuroendocrine tumors (NET): a Phase II Consortium (P2C) study. Journal of Clinical Oncology 25 (Suppl) 4504 (abstract).

Hofmann M, Maecke H, Börner R, Weckesser E, Schöffski P, Oei L, Schumacher J, Henze M, Heppeler A, Meyer J et al. 2001 Biokinetics and imaging with the somatostatin receptor PET radioligand (68)Ga-DOTATOC: preliminary data. European Journal of Nuclear Medicine 28 1751-1757.

Hubalewska-Dydejczyk A, Fröss-Baron K, Mikolajczak R, Maecke HR, Huszno B, Pach D, Sowa-Staszczak A, Janota B, Szybinski P \& Kulig J $2006{ }^{99 \mathrm{~m}}$ Tc-EDDA/ HYNIC-octreotate scintigraphy, an efficient method for the detection and staging of carcinoid tumours: results of 3 years' experience. European Journal of Nuclear Medicine and Molecular Imaging 33 1123-1133.

Janson ET \& Oberg K 1993 Long-term management of the carcinoid syndrome. Treatment with octreotide alone and in combination with alpha-interferon. Acta Oncologica 32 225-229.

Janson ET, Holmberg L, Stridsberg M, Eriksson B, Theodorsson E, Wilander E \& Oberg K 1997 Carcinoid tumors: analysis of prognostic factors and survival in 301 patients from a referral center. Annals of Oncology 8 685-690.

Kalkner KM, Janson ET, Nilsson S, Carlsson S, Oberg K \& Westlin JE 1995 Somatostatin receptor scintigraphy in patients with carcinoid tumors: comparison between radioligand uptake and tumor markers. Cancer Research 55 (Suppl 23) 5801-5804.

Kirsch CM, von Pawel J, Grau I \& Tatsch K 1994 Indium111 pentetreotide in the diagnostic work-up of patients with bronchogenic carcinoma. European Journal of Nuclear Medicine 21 1318-1325.

Kong G, Lau E, Ramdave S \& Hicks RJ 2005 High-dose In-111 octreotide therapy in combination with radiosensitizing 5-FU chemotherapy for treatment of SSR-expressing neuroendocrine tumors. Journal of Nuclear Medicine 46 (Suppl 2) 151P (abstract).

Koopmans KP, de Vries EG, Kema IP, Elsinga PH, Neels OC, Sluiter WJ, van der Horst-Schrivers AN \& Jager PL 2006 Staging of carcinoid tumours with ${ }^{18}$ F-DOPA PET: a prospective, diagnostic accuracy study. Lancet Oncology 7 728-734.

Koopmans KP, Neels OC, Kema IP, Elsinga PH, Sluiter WJ, Vanghillewe K, Brouwers AH, Jager PL \& de Vries EG 2008 Improved staging of patients with carcinoid and islet cell tumors with ${ }^{18} \mathrm{~F}$-dihydroxyphenyl-alanine and 11C-5-hydroxy-tryptophan positron emission tomography. Journal of Clinical Oncology 26 1489-1495.

Kouvaraki MA, Ajani JA, Hoff P, Wolff R, Evans DB, Lozano R \& Yao JC 2004 Fluorouracil, doxorubicin, and streptozocin in the treatment of patients with locally advanced and metastatic pancreatic endocrine carcinomas. Journal of Clinical Oncology 22 4762-4771.

Krassas GE, Dumas A, Pontikides N \& Kaltsas T 1995 Somatostatin receptor scintigraphy and octreotide treatment in patients with thyroid eye disease. Clinical Endocrinology 42 571-580.

Krenning EP, Bakker WH, Breeman WA, Koper JW, Kooij PP, Ausema L, Lameris JS, Reubi JC \& Lamberts SW 1989 Localization of endocrine related tumors with radioiodinated analogue of somatostatin. Lancet 1 242-245.

Krenning EP, Kwekkeboom DJ, Bakker WH, Breeman WAP, Kooij PPM, Oei HY, Van Hagen M, de Jong M, Reubi JC, Visser TJ et al. 1993 Somatostatin receptor scintigraphy with $\left[{ }^{111}\right.$ In-DTPA-D-Phe ${ }^{1}$ - and $\left[{ }^{123} \mathrm{I}_{-T y r}{ }^{3}\right]$-octreotide: the Rotterdam experience with more than 1000 patients. European Journal of Nuclear Medicine 20 716-731.

Kulke MH, Stuart K, Earle CC, Bhargava P, Clark JW, Enzinger PC, Meyerhardt J, Attawia M, Lawrence C \& Fuchs CS 2006 A phase II study of temozolomide and bevacizumab in patients with advanced neuroendocrine tumors. Journal of Clinical Oncology 24 (Suppl) 40-44 (abstract). 
Kulke MH, Lenz HJ, Meropol NJ, Posey J, Ryan DP, Picus J, Bergsland E, Stuart K, Tye L, Huang X et al. 2008 Activity of sunitinib in patients with advanced neuroendocrine tumors. Journal of Clinical Oncology 26 3403-3410.

Kwekkeboom DJ, Krenning EP, Bakker WH, Oei HY, Kooij PPM \& Lamberts SWJ 1993a Somatostatin analogue scintigraphy in carcinoid tumors. European Journal of Nuclear Medicine 20 283-292.

Kwekkeboom DJ, Van Urk H, Pauw KH, Lamberts SWJ, Kooij PPM, Hoogma R \& Krenning EP 1993b Octreotide scintigraphy for the detection of paragangliomas. Journal of Nuclear Medicine 34 873-878.

Kwekkeboom DJ, Reubi JC, Lamberts SWJ, Bruining HA, Mulder AH, Oei HY \& Krenning EP 1993c In vivo somatostatin receptor imaging in medullary thyroid carcinoma. Journal of Clinical Endocrinology and Metabolism 76 1413-1417.

Kwekkeboom DJ, Kho GS, Lamberts SW, Reubi JC, Laissue JA \& Krenning EP 1994 The value of octreotide scintigraphy in patients with lung cancer. European Journal of Nuclear Medicine 21 1106-1113.

Kwekkeboom DJ, Krenning EP, Kho GS, Breeman WAP \& Van Hagen PM 1998 Octreotide scintigraphy in patients with sarcoidosis. European Journal of Nuclear Medicine 25 1284-1292.

Kwekkeboom DJ, de Herder WW \& Krenning EP 1999

Receptor imaging in the diagnosis and treatment of pituitary tumors. Journal of Endocrinological Investigation 22 80-88.

Kwekkeboom DJ, Bakker WH, Kooij PP, Konijnenberg MW, Srinivasan A, Erion JL, Schmidt MA, Bugaj JL, de Jong M \& Krenning EP $2001\left[{ }^{177} \mathrm{Lu}-\mathrm{DOTA}{ }^{0} \mathrm{Tyr}^{3}\right]$ octreotate: comparison with $\left[{ }^{111}\right.$ In-DTPA $\left.{ }^{0}\right]$ octreotide in patients. European Journal of Nuclear Medicine 28 1319-1325.

Kwekkeboom DJ, Bakker WH, Kam BL, Teunissen JJ, Kooij PP, de Herder WW, Feelders RA, van Eijck CH, de Jong M, Srinivasan A et al. 2003 Treatment of patients with gastro-entero-pancreatic (GEP) tumours with the novel radiolabeled somatostatin analogue $\left[{ }^{177} \mathrm{Lu}-\mathrm{DOTA}^{0}\right.$,$\mathrm{Tyr}^{3}$ ]octreotate. European Journal of Nuclear Medicine and Molecular Imaging 30 417-422.

Kwekkeboom DJ, Mueller-Brand J, Paganelli G, Anthony LB, Pauwels S, Kvols LK, O’Dorisio TM, Valkema R, Bodei L \& Chinol M 2005a Overview of results of peptide receptor radionuclide therapy with 3 radiolabeled somatostatin analogs. Journal of Nuclear Medicine 46 (Suppl 1) 62S-66S.

Kwekkeboom DJ, Teunissen JJ, Bakker WH, Kooij PP, de Herder WW, Feelders RA, van Eijck CH, Esser JP, Kam BL \& Krenning EP 2005b Treatment with the radiolabeled somatostatin analogue $\left[{ }^{177} \mathrm{Lu}^{-D O T A}{ }^{0}, \mathrm{Tyr}^{3}\right]$ octreotate in patients with gastro-entero-pancreatic (GEP) tumors. Journal of Clinical Oncology 23 2754-2762.

Kwekkeboom DJ, de Herder WW, Kam BL, van Eijck CH, van Essen M, Kooij PP, Feelders RA, van Aken MO \& Krenning EP 2008 Treatment with the radiolabeled somatostatin analog $\left[{ }^{177} \mathrm{Lu}-\mathrm{DOTA}^{0}, \mathrm{Tyr}^{3}\right]$ octreotate: toxicity, efficacy, and survival. Journal of Clinical Oncology 26 2124-2130.

Lebtahi R, Cadiot G, Sarda L, Daou D, Faraggi M, Petegnief Y, Mignon M \& le Guludec D 1997 Clinical impact of somatostatin receptor scintigraphy in the management of patients with neuroendocrine gastroenteropancreatic tumors. Journal of Nuclear Medicine 38 853-858.

Lebtahi R, Le Cloirec J, Houzard C, Daou D, Sobhani I, Sassolas G, Mignon M, Bourguet P \& Le Guludec D 2002 Detection of neuroendocrine tumors: $(99 \mathrm{~m}) \mathrm{Tc}-\mathrm{P} 829$ scintigraphy compared with (111)In-pentetreotide scintigraphy. Journal of Nuclear Medicine 43 889-895.

Lugtenburg PJ, Löwenberg B, Valkema R, Oei HY, Lamberts SW, Eijkemans MJ, van Putten WL \& Krenning EP $2001 a$ Somatostatin receptor scintigraphy in the initial staging of low-grade non-Hodgkin's lymphomas. Journal of Nuclear Medicine 42 222-229.

Lugtenburg PJ, Krenning EP, Valkema R, Oei HY, Lamberts SW, Eijkemans MJ, van Putten WL \& Löwenberg B $2001 b$ Somatostatin receptor scintigraphy useful in stage I-II Hodgkin's disease: more extended disease identified. British Journal of Haematology 112 936-944.

Mazzaglia PJ, Berber E, Milas M \& Siperstein AE 2007 Laparoscopic radiofrequency ablation of neuroendocrine liver metastases: a 10-year experience evaluating predictors of survival. Surgery 142 10-19.

Meisetschläger G, Poethko T, Stahl A, Wolf I, Scheidhauer K, Schottelius M, Herz M, Wester HJ \& Schwaiger M 2006 Gluc-Lys $\left(\left[{ }^{18} \mathrm{~F}\right] \mathrm{FP}\right)$-TOCA PET in patients with SSTRpositive tumors: biodistribution and diagnostic evaluation compared with [ $\left.{ }^{111} \mathrm{In}\right] \mathrm{DTPA}$-octreotide. Journal of Nuclear Medicine 47 566-573.

Menda Y \& Kahn D 2002 Somatostatin receptor imaging of non-small lung cancer with ${ }^{99 \mathrm{~m}} \mathrm{Tc}$ depreotide. Seminars in Nuclear Medicine 32 92-96.

Moertel CG 1983 Treatment of the carcinoid tumor and the malignant carcinoid syndrome. Journal of Clinical Oncology 1 727-740.

Moertel CG, Hanley JA \& Johnson LA 1980 Streptozocin alone compared with streptozocin plus fluorouracil in the treatment of advanced islet-cell carcinoma. New England Journal of Medicine 303 1189-1194.

Moertel CG, Lefkopoulo M, Lipsitz S, Hahn RG \& Klaassen D 1992 Streptozocin-doxorubicin, streptozocin-fluorouracil or chlorozotocin in the treatment of advanced islet-cell carcinoma. New England Journal of Medicine 326 519-523.

Neijt JP, Lacave AJ, Splinter TA, Taal BG, Veenhof CH, Sahmoud T \& Lips CJ 1995 Mitoxantrone in metastatic apudomas: a phase II study of the EORTC Gastro-Intestinal Cancer Cooperative Group. British Journal of Cancer 71 106-108.

O’Toole D, Hentic O, Corcos O \& Ruszniewski P 2004 Chemotherapy for gastro-enteropancreatic endocrine tumours. Neuroendocrinology 80 (Suppl 1) 79-84. 
Otte A, Herrmann R, Heppeler A, Behe M, Jermann E, Powell P, Maecke HR \& Muller J 1999 Yttrium-90 DOTATOC: first clinical results. European Journal of Nuclear Medicine 26 1439-1447.

Paganelli G, Bodei L, Handkiewicz Junak D, Rocca P, Papi S, Lopera Sierra M, Gatti M, Chinol M, Bartolomei M, Fiorenza M et al. $2002{ }^{90}$ Y-DOTA-D-Phe ${ }^{1}-$ Tyr $^{3}$-octreotide in therapy of neuroendocrine malignancies. Biopolymers 66 393-398.

Postema PTE, Krenning EP, Wijngaarde R, Kooy PP, Oei HY, van den Bosch WA, Reubi JC, Wiersinga WM, Hooijkaas H, van der Loos T et al. 1994 [ ${ }^{111}$ In-DTPAD-Phe ${ }^{1}$ ]-octreotide scintigraphy in thyroidal and orbital Graves' disease: a parameter for disease activity? Journal of Clinical Endocrinology and Metabolism 79 1845-1851.

Postema PTE, De Herder WW, Reubi JC, Oei HY, Kwekkeboom DJ, Bruining HJ, Bonjer J, van Toor H, Hennemann G \& Krenning EP 1996 Somatostatin receptor scintigraphy in nonmedullary thyroid cancer. Digestion 1 36-37.

Quaedvlieg PF, Visser O, Lamers CB, Janssen-Heijen ML \& Taal BG 2001 Epidemiology and survival in patients with carcinoid disease in The Netherlands. An epidemiological study with 2391 patients. Annals of Oncology 12 1295-1300.

Quigley AM, Buscombe JR, Shah T, Gnanasegaran G, Roberts D, Caplin ME \& Hilson AJ 2005 Intertumoural variability in functional imaging within patients suffering from neuroendocrine tumours. An observational, crosssectional study. Neuroendocrinology 82 215-220.

Reisinger I, Bohuslavitzki KH, Brenner W, Braune S, Dittrich I, Geide A, Kettner B, Otto HJ, Schmidt S \& Munz DL 1998 Somatostatin receptor scintigraphy in small-cell lung cancer: results of a multicenter study. Journal of Nuclear Medicine 39 224-227.

Reubi JC 1997 Regulatory peptide receptors as molecular targets for cancer diagnosis and therapy. Quarterly Journal of Nuclear Medicine 41 63-70.

Reubi JC, Waser B, Krenning EP, Markusse HM, Vanhagen M \& Laissue JA 1994 Vascular somatostatin receptors in synovium from patients with rheumatoid arthritis. European Journal of Pharmacology 271 371-378.

Reubi JC, Schaer JC, Waser B, Wenger S, Heppeler A, Schmitt JS \& Mäcke HR 2000 Affinity profiles for human somatostatin receptor sst1-sst5 of somatostatin radiotracers selected for scintigraphic and radiotherapeutic use. European Journal of Nuclear Medicine 27 273-282.

Reubi JC, Waser B, Schaer JC \& Laissue JA 2001 Somatostatin receptor sst1-sst5 expression in normal and neoplastic human tissues using receptor autoradiography with subtype-selective ligands. European Journal of Nuclear Medicine 28 836-846.

Rich TA, Shepard RC \& Mosley ST 2004 Four decades of continuing innovation with fluorouracil: current and future approaches to fluorouracil chemoradiation therapy. Journal of Clinical Oncology 22 2214-2232.
Rinke A, Müller HH, Schade-Brittinger C, Klose KJ, Barth P, Wied M, Mayer C, Aminossadati B, Pape UF, Bläker M et al. 2009 Placebo-controlled, double-blind, prospective, randomized study on the effect of octreotide LAR in the control of tumor growth in patients with metastatic neuroendocrine midgut tumors: a report from the PROMID Study Group. Journal of Clinical Oncology 27 4656-4663.

Ritzel U, Leonhardt U, Stockmann F \& Ramadori G 1995 Treatment of metastasized midgut carcinoids with dacarbazine. American Journal of Gastroenterology 90 627-631.

Schmidt M, Scheidhauer K, Luyken C, Voth E, Hildebrandt G, Klug N \& Schicha H 1998 Somatostatin receptor imaging in intracranial tumours. European Journal of Nuclear Medicine 25 675-686.

Strosberg JR, Choi J, Gardner N \& Kvols L 2008 First-line treatment of metastatic pancreatic endocrine carcinomas with capecitabine and temozolomide. Journal of Clinical Oncology 26 (Suppl) 4612 (abstract).

Sun W, Lipsitz S, Catalano P, Mailliard JA, Haller DG \& Eastern Cooperative Oncology Group 2005 Phase II/III study of doxorubicin with fluorouracil compared with streptozocin with fluorouracil or dacarbazine in the treatment of advanced carcinoid tumors: Eastern Cooperative Oncology Group Study E1281. Journal of Clinical Oncology 23 4897-4904.

Telischi FF, Bustillo A, Whiteman ML, Serafini AN, Reisberg MJ, Gomez-Marin O, Civantos J \& Balkany TJ 2000 Octreotide scintigraphy for the detection of paragangliomas. Otolaryngology and Head and Neck Surgery 122 358-362.

Teunissen JJ, Kwekkeboom DJ \& Krenning EP 2004 Quality of life in patients with gastroenteropancreatic tumors treated with $\left[{ }^{177} \mathrm{Lu}\right.$-DOTA $\left.{ }^{0}, \mathrm{Tyr}^{3}\right]$ octreotate. Journal of Clinical Oncology 22 2724-2729.

Tisell LE, Ahlman H, Wängberg B, Hansson G, Mölne J, Nilsson O, Lindstedt G, Fjälling M \& Forssell-Aronsson E 1997 Somatostatin receptor scintigraphy in medullary thyroid carcinoma. British Journal of Surgery 84 543-547.

Valkema R, de Jong M, Bakker WH, Breeman WA, Kooij PP, Lugtenburg PJ, De Jong FH, Christiansen A, Kam BL, De Herder WW et al. 2002 Phase I study of peptide receptor radionuclide therap1y with $\left[{ }^{111}{ }^{1 n}-D_{T P A}{ }^{0}\right]$ Octreotide: the Rotterdam experience. Seminars in Nuclear Medicine 32 110-122.

Valkema R, Pauwels S, Kvols L, Jamar F, Barone R, Bakker WH, Lasher J \& Krenning EP 2003 Long-term follow-up of a phase 1 study of peptide receptor radionuclide therapy (PRRT) with $\left[{ }^{90} \mathrm{Y}-\mathrm{DOTA}^{0}, \mathrm{Tyr}^{3}\right]$ octreotide in patients with somatostatin receptor positive tumours. European Journal of Nuclear Medicine and Molecular Imaging 30 (Suppl 2) S232 (abstract).

Valkema R, Pauwels S, Kvols LK, Barone R, Jamar F, Bakker WH, Kwekkeboom DJ, Bouterfa H \& Krenning 
EP 2006 Survival and response after peptide receptor radionuclide therapy with $\left[{ }^{90} \mathrm{Y}\right.$-DOTA $\left.{ }^{0}, \mathrm{Tyr}^{3}\right]$ octreotide in patients with advanced gastroenteropancreatic neuroendocrine tumors. Seminars in Nuclear Medicine 36 147-156.

Van der Harst E, de Herder WW, Bruining HA, Bonjer HJ, de Krijger RR, Lamberts SWJ, van de Meiracker AH, Boomsma F, Stijnen T, Krenning EP et al. 2001 [(123)I]metaiodobenzylguanidine and [(111)In]octreotide uptake in begnign and malignant pheochromocytomas. Journal of Clinical Endocrinology and Metabolism 86 685-693.

Van Eijck CH, Krenning EP, Bootsma A, Oei HY, van Pel R, Lindemans J, Jeekel J, Reubi JC \& Lamberts SW 1994 Somatostatin-receptor scintigraphy in primary breast cancer. Lancet 343 640-643.

Van Essen M, Krenning EP, Kam BL, de Herder WW, van Aken MO \& Kwekkeboom DJ 2008 Report on short-term side effects of treatments with (177)Luoctreotate in combination with capecitabine in seven patients with gastroenteropancreatic neuroendocrine tumours. European Journal of Nuclear Medicine and Molecular Imaging 35 743-748.

Vanhagen PM, Krenning EP, Reubi JC, Kwekkeboom DJ, Bakker WH, Mulder AH, Laissue I, Hoogstede HC \& Lamberts SWJ 1994 Somatostatin analogue scintigraphy in granulomatous diseases. European Journal of Nuclear Medicine 21 497-502.

Virgolini I, Britton K, Buscombe J, Moncayo R, Paganelli G \& Riva P $2002{ }^{111}$ In- and ${ }^{90}$ Y-DOTA-Lanreotide: results and implications of the MAURITIUS trial. Seminars in Nuclear Medicine 32 148-155.

Waldherr C, Pless M, Maecke HR, Haldemann A \& MuellerBrand J 2001 The clinical value of $\left[{ }^{90}\right.$ Y-DOTA]-D-Phe ${ }^{1}$ $\mathrm{Tyr}^{3}$-octreotide $\left({ }^{90} \mathrm{Y}\right.$-DOTATOC) in the treatment of neuroendocrine tumours: a clinical phase II study. Annals of Oncology 12 941-945.

Waldherr C, Pless M, Maecke HR, Schumacher T, Crazzolara A, Nitzsche EU, Haldemann A \& Mueller-Brand J 2002a
Tumor response and clinical benefit in neuroendocrine tumors after 7.4 GBq (90)Y-DOTATOC. Journal of Nuclear Medicine 43 610-616.

Waldherr C, Schumacher T, Maecke HR, Schirp U, Forrer F, Nitzsche EU \& Mueller-Brand J 2002b Does tumor response depend on the number of treatment sessions at constant injected dose using 90Yttrium-DOTATOC in neuroendocrine tumors? European Journal of Nuclear Medicine and Molecular Imaging 29 (Suppl 1) S100 (abstract).

Wehrmann C, Senftleben S, Zachert C, Müller D \& Baum RP 2007 Results of individual patient dosimetry in peptide receptor radionuclide therapy with ${ }^{177} \mathrm{Lu}$ DOTA-TATE and ${ }^{177}$ Lu DOTA-NOC. Cancer Biotherapy \& Radiopharmaceuticals 22 406-416.

Westlin JE, Janson ET, Arnberg H, Ahlstrom H, Oberg K \& Nilsson S 1993 Somatostatin receptor scintigraphy of carcinoid tumours using the $\left[{ }^{111}\right.$ In-DTPA-D-Phe ${ }^{1}$ ] octreotide. Acta Oncologica 32 783-786.

Wong JY, Shibata S, Williams LE, Kwok CS, Liu A, Chu DZ, Yamauchi DM, Wilczynski S, Ikle DN, Wu AM et al. 2003 A phase I trial of 90Y-anti-carcinoembryonic antigen chimeric T84.66 radioimmunotherapy with 5 -fluorouracil in patients with metastatic colorectal cancer. Clinical Cancer Research 9 5842-5852.

Yao JC, Zhang JX, Rashid A, Yeung SC, Szklaruk J, Hess K, Xie K, Ellis L, Abbruzzese JL \& Ajani JA 2007 Clinical and in vitro studies of imatinib in advanced carcinoid tumors. Clinical Cancer Research 13 234-240.

Yao JC, Phan AT, Chang DZ, Wolff RA, Hess K, Gupta S, Jacobs C, Mares JE, Landgraf AN, Rashid A et al. 2008 Efficacy of RAD001 (everolimus) and octreotide LAR in advanced low- to intermediate-grade neuroendocrine tumors: results of a phase II study. Journal of Clinical Oncology 26 4311-4318.

Zimmer T, Stolzel U, Bäder M, Koppenhagen K, Hamm B, Buhr H, Riecken EO \& Wiedenmann B 1996 Endoscopic ultrasonography and somatostatin receptor scintigraphy in the preoperative localisation of insulinomas and gastrinomas. Gut 39 562-568. 